\title{
Transport of dust particles from the Bodélé region to the monsoon layer - AMMA case study of the 9-14 June 2006 period
}

\author{
S. Crumeyrolle ${ }^{1,2}$, P. Tulet ${ }^{2,3}$, L. Gomes ${ }^{2}$, L. Garcia-Carreras ${ }^{4}$, C. Flamant ${ }^{5}$, D. J. Parker ${ }^{4}$, A. Matsuki ${ }^{1,6}$, \\ P. Formenti ${ }^{7}$, and A. Schwarzenboeck ${ }^{1}$ \\ ${ }^{1}$ Laboratoire de Météorologie Physique, Université Blaise Pascal, UMR 6016, Clermont-Ferrand, France \\ ${ }^{2}$ Centre National de Recherches Météorologiques, GAME, Météo-France, Toulouse, France \\ ${ }^{3}$ LACy, Université de La Réunion, Saint-Denis, France \\ ${ }^{4}$ School of Earth and Environment, University of Leeds, Leeds, LS2 9JT, UK \\ ${ }^{5}$ LATMOS/IPSL, CNRS-UPMC-UVSQ, Paris, France \\ ${ }^{6}$ Frontier Science Organization, Kanazawa University, Japan \\ ${ }^{7}$ LISA/IPSL, Universités Paris 12 et Paris 7, CNRS, UMR 6240, Créteil, France
}

Received: 25 January 2010 - Published in Atmos. Chem. Phys. Discuss.: 22 February 2010

Revised: 27 December 2010 - Accepted: 6 January 2011 - Published: 17 January 2011

\begin{abstract}
Aerosol properties were measured during an airborne campaign experiment that took place in June 2006 in West Africa within the framework of the African Monsoon Multidisciplinary Analyses (AMMA). The goal of the present study was to investigate a dynamical mechanism able to facilitate the sedimentation of dust particles from the Saharan Air Layer (SAL) into the boundary layer. A significant change in the dust particle concentration measured along the meridian between Niamey (Niger) and Cotonou (Benin) was found in the boundary layer $(\sim 700 \mathrm{~m})$, where the dust particle concentration increased in a zone where local emission is not possible. Moreover, the boundary layer top observed with the dropsondes launched with the F-F20 shows a strong relationship with the surface cover anomalies, with higher Boundary Layer (BL) tops over the warmer surfaces, such as croplands, as opposed to adjacent forest. A mesoscale atmospheric model with a new on-line dust parameterization, resulting from the Alfaro and Gomes (2001) parametrisation and AMMA observations, was used to interpret the impact of vegetation anomalies on dust particle sedimentation. The results of the simulation are consistent with the observations, with higher dust concentration over the warm surface cover anomalies.
\end{abstract}



Correspondence to: S. Crumeyrolle (s.crumeyrolle@opgc.univ-bpclermont.fr)

\section{Introduction}

Mineral dust represents the second largest component of primary particle emissions by mass, with an estimated global source strength of 1000 to $3000 \mathrm{Mt} / \mathrm{yr}$ (Ginoux et al., 2001; Houghton et al., 2001). Mineral dust consists of soil particles liberated by the wind at the surface and which can be raised to considerable tropospheric altitudes by the strong convective regimes that might develop over the desert. As a result, dust particles are transported by the winds to Europe, Middle Eastern regions and South America (e.g. Prodi and Fea, 1979; Levin et al., 1980; Talbot et al., 1986; Guerzoni et al., 1997; Avila et al., 1997; Prospero, 1999; Gobbi et al., 2003). These particles contribute significantly to the global radiative budget through absorption and scattering of longwave and shortwave radiation (Houghton et al., 2001), and their indirect effect on cloud microphysics (Intergovernmental Panel in Climate Change, 2007; Twomey, 1977; Albrecht, 1989; Sandu et al., 2008). The mineral dust particle effect depends on their physical, mineralogical and chemical properties that, in turn, depend on source area mineralogy, and processes on the particle surfaces during transport in dry or aqueous phases (Levin et al., 1996; Goudie and Middleton, 2001; Luo et al., 2003; Crumeyrolle et al., 2008).

Over West Africa, dust emission events occur regularly over the Tibesti and Ennedi mountains in Chad, and over the Bodélé depression due to an enhanced low-level jet feature (Washington and Todd, 2005; Washington et al., 2006; Warren et al., 2007; Todd et al., 2008b). After being transported

Published by Copernicus Publications on behalf of the European Geosciences Union. 
within the Harmattan flux, which comprises the northeasterly trade winds, dust particles are observed in the Saharan Air Layer (SAL, Karyampudi et al., 1999; Cuesta et al., 2009; Flamant et al., 2009b). The SAL, localised above the monsoon layer, is decoupled from the surface below and is more closely linked to the desert regions (Parker et al., 2005a). Then, the presence of aerosol in the SAL is connected to long range transport from Sahelian and Saharan regions. Because of the potential of air-suspended particles for long range transport and the way these particles interact with solar and terrestrial radiation, the sedimentation process of dust particles could impact on the atmospheric stratification and thereby may modify the West African weather, and is of a major interest.

The goal of the present study is to better understand the mesoscale process that affects the dust sedimentation during its transport and to quantify the fraction of dust that is sedimented in the boundary layer during a major springtime dust event from the Bodélé and Sudan regions (Flamant et al., 2009a) in the framework of the African Monsoon Multidisciplinary Analysis (AMMA, www.amma-international.org/, Redelsperger et al., 2006). Recent modelling studies show the presence of exchanges for boundaries between different vegetation types (Hong et al., 1995; Pinty et al., 1989). Despite the high number of modelling studies that predict the presence of land surface induced vertical exchanges between the boundary layer and free troposphere, few observational studies have demonstrated their existence. Garcia-Carreras et al. (2010) related the vegetation anomalies to the vertical transport of isoprene from the surface to the upper layers. This result highlights strong exchanges from the monsoon flux into the Harmattan layer. For this purpose, airborne (ATR-42) measurements were conducted in June 2006 along the meridian between Niamey (Niger) and Cotonou (Benin).

This paper describes the measurements of particle concentrations, optical properties and dynamical features observed during this period. Additionally, a mesoscale model with online dust parameterization was used to interpret the impact of the vegetation anomalies on the dust particle sedimentation process. The airborne sampling strategy is described in Sect. 2. The Meso-NH mesoscale model using an explicit representation of aerosol processes is presented in Sect. 3. Section 4 outlines the observations combined with the simulation results.

\section{Instrumentation}

The measurements were performed during the Special Observation Period \#1a (SOP1a) of the AMMA experiment on the french aircrafts (ATR-42 and F-Falcon 20) operated by the Service des Avions Français Instruments pour la Recherche en Environnement (SAFIRE). For details of the overall SOP instrumentation and its coordination, refer to Lebel et al. (2010). These aircraft were based at Niamey air-

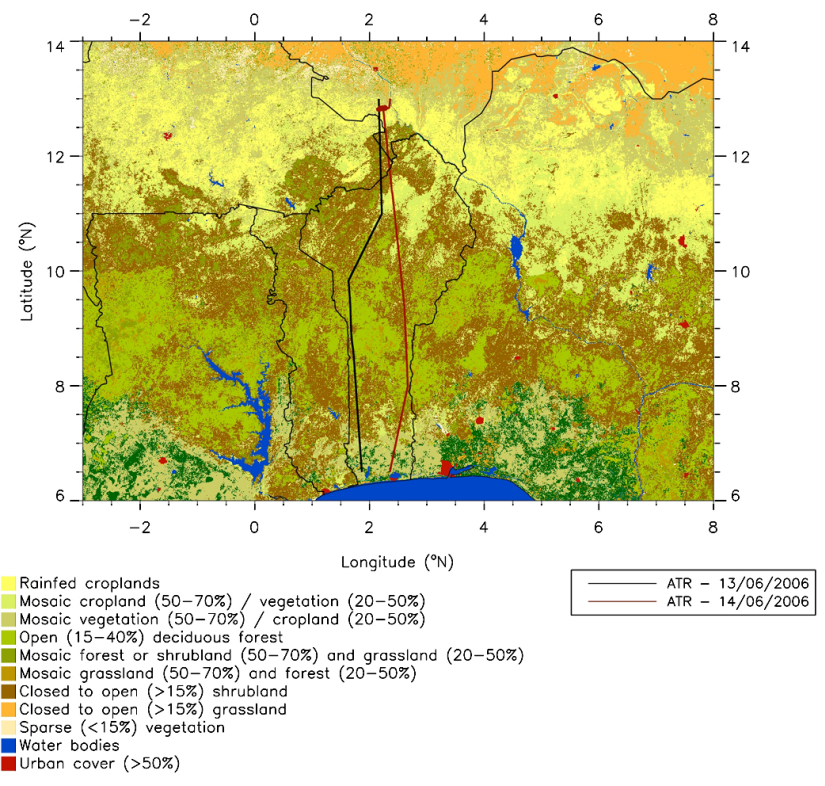

Fig. 1. GlobCover Land Cover map, with the flight plans of the ATR-42 on 13 and 14 June 2006. The map is derived from a time series of MERIS FR mosaics using the UN land Cover Classification System (Source data: ESA/ESA Globcover project, led by MEDIAS-France/POSTEL).

port in Niger for the duration of the AMMA SOPs (Reeves et al., 2010) and performed two combined research flights during June 2006. These two combined flight patterns were conducted on 13 and 14 June 2006 along a meridian between Niamey (Niger) and Cotonou (Benin), located $750 \mathrm{~km}$ south of Niamey.

These flights occurred during the early afternoon when the convective mixed layer was growing relatively slowly, and the flight plans (Fig. 1) were similar. Along the meridian, the ATR-42 flew at one constant altitude $(700 \mathrm{~m}$ above mean sea level) in the Boundary Layer (BL) while the French Falcon 20 (F-F20) flew in the free troposphere above the Saharan Air Layer ( $8000 \mathrm{~m}$ above mean sea level). Only one sounding was performed with the ATR-42 (14 June 2006), providing a rapid characterization of the inversion level and of the vertical profile of the thermodynamic and microphysical parameters, at the end of the flight. Twelve and one dropsondes were released from the Falcon-20 on 13 and 14 June, respectively (Flamant et al., 2009a).

On the ATR-42, two aerosol inlets were installed: the French Community Aerosol Inlet (CAI) and AVIRAD. The CAI is an isokinetic and isoaxial inlet with a 50\% sampling efficiency measured for a geometric diameter of $4.5 \mu \mathrm{m}$ (Gomes et al., 2010) on which an aerosol instrumentation set was connected (Crumeyrolle et al., 2008). Two condensation particle counters (CPC TSI model 3025 and 3010, respectively) were used to measure total ambient aerosol concentrations $(\mathrm{CN})$, a scanning mobility particle sizer (SMPS) 

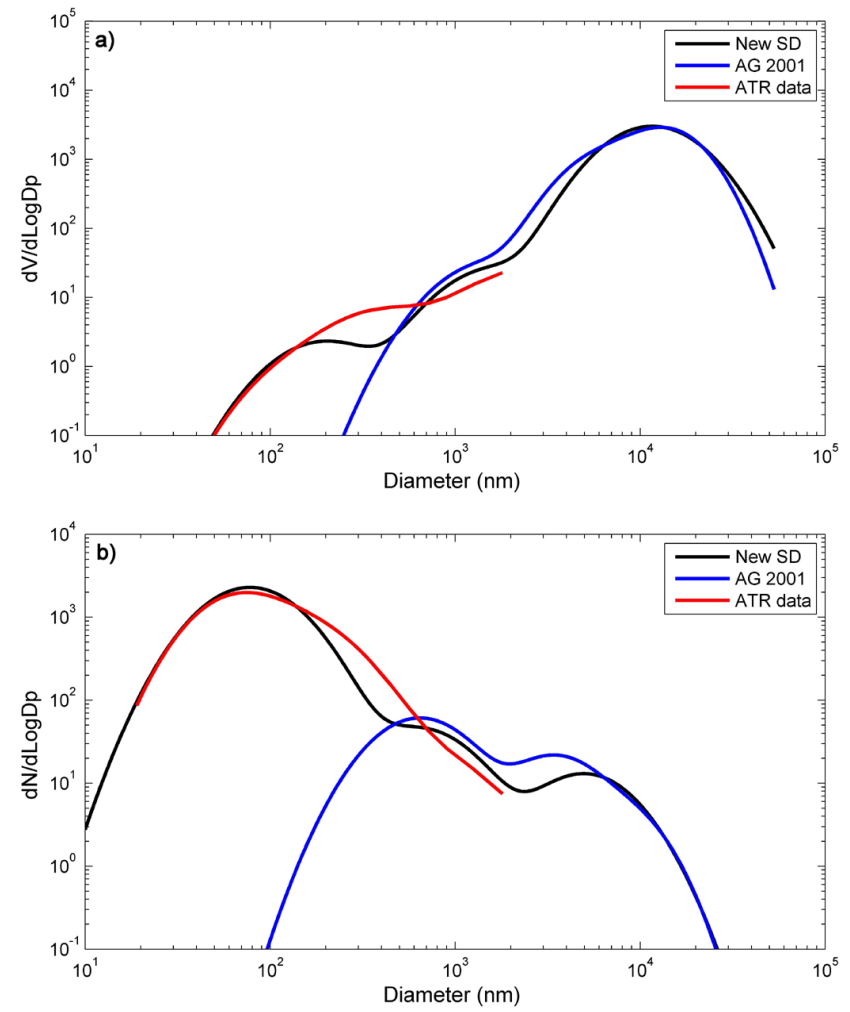

Fig. 2. Volume (a) and Number (b) size distribution of particles given by Alfaro and Gomes (2001) (blue line), by ATR-42 observations (red line) and the new size distribution (black line) proposed in this study and used in the Meso-NH parametrisation.

was used to measure the number distribution of aerosol particles with diameters from 0.02 to $0.3 \mu \mathrm{m}$ and an optical particle sizer (OPS, GRIMM model 1.108) provided particle size distributions ranging from 0.3 to $2 \mu \mathrm{m}$ equivalent optical diameter. Data collected are used to provide the number and mass concentration. AVIRAD is an isokinetic inlet able to collect particles up to $8 \mu \mathrm{m}$ in diameter (Filippi, 2000; Formenti et al., 2010). AVIRAD is connected to two parallel sampling lines for bulk filtration, two parallel sampling lines for 4-stage Dekati impactors, a three-wavelength (450, $550,700 \mathrm{~nm}$ ) nephelometer (model 3563, TSI Inc.), a sevenwavelength aethalometer (model AE31, Magee Sci.), and an optical particle sizer (OPS, GRIMM model 1.108) providing particle size distribution ranging from 0.3 to $17 \mu \mathrm{m}$ optical equivalent diameter. The ATR- 42 was also equipped for the measurements of wind, turbulent fluxes, and atmospheric state parameters.

\section{Mesoscale modelling}

\subsection{Description}

The mesoscale non-hydrostatic atmospheric model MesoNH was used in this study to complement the observations. This model has been jointly developed by CNRM (Meteo France) and Laboratoire d'Aérologie (CNRS) (Lafore et al., 1998). MesoNH simulates atmospheric conditions in the small scale (Large-Eddy Simulation type, horizontal resolution of a few metres) and synoptic scale (horizontal resolution of several tens of kilometres) and can be run in a two-way nested mode involving up to 8 nesting stages. Different sets of parameterizations have been introduced for convection (Bechtold et al., 2001), cloud microphysics (Pinty and Jabouille, 1998; Cohard and Pinty, 2000), turbulence (Bougeault and Lacarrere, 1989), biosphere-atmosphere thermodynamic exchanges (ISBA) (Noilhan and Mahouf, 1996), urbanatmosphere interactions (Masson, 2000), lightning processes (Barthe et al., 2005), gaseous chemistry (Suhre et al., 1998; Tulet et al., 2003) and aerosol chemistry (Tulet et al., 2005).

A spin up time of one day has been used and tested in recent studies (Grini, 2006; Crumeyrolle, 2009; Tulet, 2008, 2010). Thus, the simulation begins at 00:00 UTC on 08 June 2006, and ends at 00:00 UTC on 14 June 2006. Two two-way nested grid domains were used. The large domain $\left(36 \mathrm{~km}\right.$ resolution) between $3.1^{\circ} \mathrm{S}$ and $31.7^{\circ} \mathrm{N}$ in latitude and $25.64^{\circ} \mathrm{W}$ and $35.64^{\circ} \mathrm{E}$ in longitude, gives a large scale synoptic view of west Africa. The embedded domain ( $5 \mathrm{~km}$ resolution) is centred over Benin and the eastern part of Niger (latitudes $4.9^{\circ} \mathrm{N}$ and $16.8^{\circ} \mathrm{N}$ and longitudes $2.2^{\circ} \mathrm{W}$ and $5.36^{\circ} \mathrm{E}$ ) and gives a fine-scale view of the meridian between Niamey and Cotonou. The vertical resolution is composed of 60 stretched vertical levels reaching the altitude of $34 \mathrm{~km}$; 30 levels are located in the boundary layer between the surface and $2000 \mathrm{~m}$. The temporal resolution varies with the spatial resolution of the domain. In the larger domain (36km), the temporal resolution is $\sim 20 \mathrm{~s}$ and $\sim 5 \mathrm{~s}$ in the smaller domain $(5 \mathrm{~km})$. Initialization and lateral boundary conditions of the large domain were taken from the ECMWF analysis. As land surface data used by the AMMA community (ALMIP, Boone et al., 2009; De Rosnay et al., 2009) are not covering completely our first domain of simulation, soil moisture fields are generated from the ECMWF data. Vegetation types came from the ECOCLIMAP data base (Masson et al., 2003). The resolution of the ECOCLIMAP climatology is of $1 \mathrm{~km}$.

\subsection{Parameterization of dust size distribution}

The modelling of the size distribution of mineral dust at the emission is generally treated using the Alfaro and Gomes (2001) dust parameterization (AG01), in which the dust mass size spectrum is represented by three lognormal modes with diameters centred on 1.5, 6.7 and $14.2 \mu \mathrm{m}$ (Fig. 2). The corresponding mass fractions are about $1 \%, 36 \%$ and $63 \%$. The corresponding median diameters for the number size distribution are $0.64,3.45$, and 8.67 , respectively, with $74 \%$ of the number concentration in the finer mode centred at $0.64 \mu \mathrm{m}$ (Fig. 2). During the June SOP, a number size distribution was measured onboard the ATR-42 during flight 21, while 
the aircraft was flying very close above the ground near a source area. This measurement confirms the existence of a particle mode centred around $0.64 \mu \mathrm{m}$ but indicates that almost $99 \%$ of the number concentration is included in two other particle modes finer than that centred around $0.64 \mu \mathrm{m}$ (Fig. 2b). Even if the AG01 parameterization well represents the mass fluxes of emitted particles, it seems largely underestimate the number concentrations of fine particles.

To improve the dust size spectrum parameterisation (Todd et al., 2008a), we propose to build a new size spectrum composed of three modes based on the AG01 scheme and the AMMA observations. The particle mode of the number distribution centred on $0.64 \mu \mathrm{m}$, which is common to AMMA observations and AG01 scheme, is used as the reference particle mode.

The new dust size spectrum is constrained in order to have the same total number concentration as the observed number size distribution and the same total volume concentration as the AG01 scheme. Thus, to represent the mass size distribution of this new scheme, we have introduced a larger mode $(D p=11.6 \mu \mathrm{m})$ derived from a combination of the larger particle modes of AG01 by respecting the sum of their volume fraction $(99 \%)$. Then, to better represent the number concentration, we have introduced a fine mode $(D p=0.2 \mu \mathrm{m})$ derived from a combination of the finer particle modes observed during the AMMA flight 21 and respecting the total number concentration observed $\left(1430 \mathrm{~cm}^{-3}\right)$. Finally, the dust number and mass size spectra are represented by three lognormal modes (Fig. 2). The lognormal parameters of the deduced size distribution which will be used in MesoNH are given in Table 1. With this new size distribution (NSD), the number concentrations, made of more than $97 \%$ of fine particles, are considerably improved. As a result, the impact of very small particles on the radiative budget and their feedback on the West African weather should be appreciably better represented. Furthermore, the aerosol budget may be compared to the observations and fixed with three variables: the aerosol optical depth (AOD), the mass concentration and the number concentration.

Mineral dust emission and transport are parameterized by Grini et al. (2006). Regarding emission processes, dust aerosols are mobilized using the Dust Entrainment and Deposition model (DEAD) (Zender et al., 2003) which calculates dust fluxes from wind friction speeds. The physical basis of the model is taken from Marticorena and Bergametti (1995) where dust fluxes are calculated as a function of saltation and sandblasting processes. Here, the emission of dust aerosols is calculated directly from Interactions between the Soil Biosphere and Atmosphere (ISBA) surface parameters, and then sent to the atmosphere consistent with the fluxes of momentum, energy and humidity. In this parameterization, the three dust aerosol populations, proposed in this study, are transported by the ORILAM lognormal aerosol scheme (Tulet et al., 2005).
Table 1. Log-normal parameters of the size distribution used in the MesoNH model.

\begin{tabular}{llll}
\hline Dust mode & fine & medium & coarse \\
\hline Number fraction $(\%)$ & 97.52 & 1.95 & 0.52 \\
Mass fraction $(\%)$ & 0.08 & 0.92 & 99 \\
Geometric Standard deviation & 1.75 & 1,76 & 1,70 \\
Number median diameter $(\mu \mathrm{m})$ & 0.078 & 0.64 & 5.0 \\
Mass median diameter $(\mu \mathrm{m})$ & 0.20 & 1.67 & 11.6 \\
\hline
\end{tabular}

To interpret the observational results, four different simulations have been performed by using the mesoscale non hydrostatic atmospheric model MesoNH. First, to highlight sedimentation processes, two different simulations have been realized, one which takes into account the dust sedimentation (SED) and the other one which does not (NOSED). The comparison of the results is only possible if the atmospheric dynamics are consistent between the two simulations. As dust particles have a large impact on the radiative budget and thus on the atmospheric dynamics, both absorption and, most importantly, diffusion of dust particles have to be turned off in both simulations. However, in reality dynamical features may have a feedback on the stratification of the dust particles in the atmosphere. Then, for each simulation (SED and NOSED), two versions have been carried out: one where the radiative impact of dust has been taken into account (RAD) and another one without this radiative impact.

To assess the dynamical impact of dust particles, the differences between RAD and NORAD simulations were investigated. The results show that the surface level wind speed is underestimated as a function of latitude, when the diffusion of dust particles is turned off (NORAD). Indeed, the maximum surface level wind speed is underestimated by $51 \%$ and $17 \%$ in Agoufou (northern ground site) and in Djougou (southern ground site), respectively. Consequently, the aerosol optical depth is also underestimated (by a maximum of $25 \%$ over Djougou). Despite these differences, the sedimentation process occurs exactly in the same area (between $6^{\circ} \mathrm{N}$ and $9^{\circ} \mathrm{N}$ ) in the RAD or NORAD simulation.

In the following parts, the dynamical features will be discussed using the simulation RAD-SED. Since dust particle transport is currently treated using an off-line chemical transport model (Grini et al., 2002; Myhre et al., 2003; Berglen et al., 2004; Endresen et al., 2003; Gauss et al., 2003; Grini et al., 2004), the processes leading to sedimentation will be explored using the NORAD-SED and NORAD-NOSED simulations.

\subsection{Comparison of observed and simulated parameters}

\subsubsection{Aerosol distribution}

During the period from 9 to 14 June 2006, satellite data indicate that numerous dust sources were active 

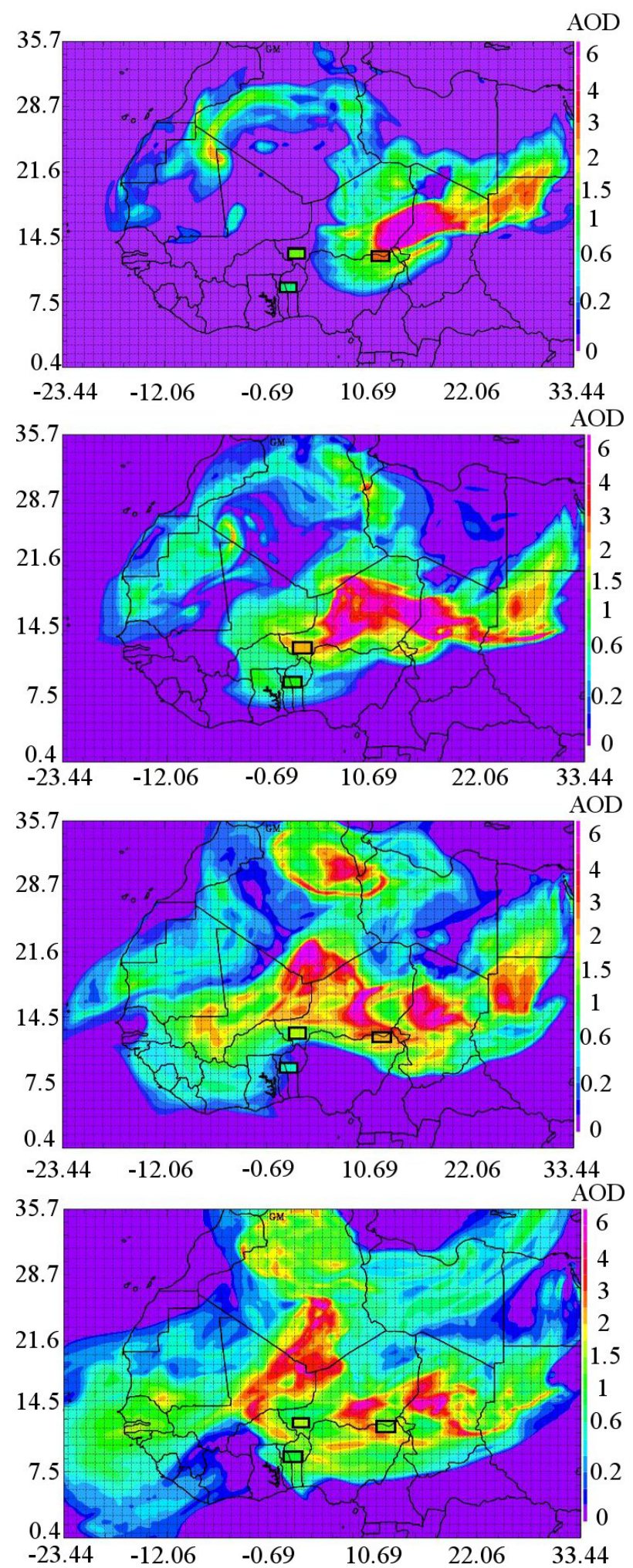

Fig. 3. Daily Aerosol Optical Depth over West Africa from 9 to 12 June 2006, around 12:00 UTC. The simulated AOD values are represented on the whole domain while the observed AOD are represented in boxes.
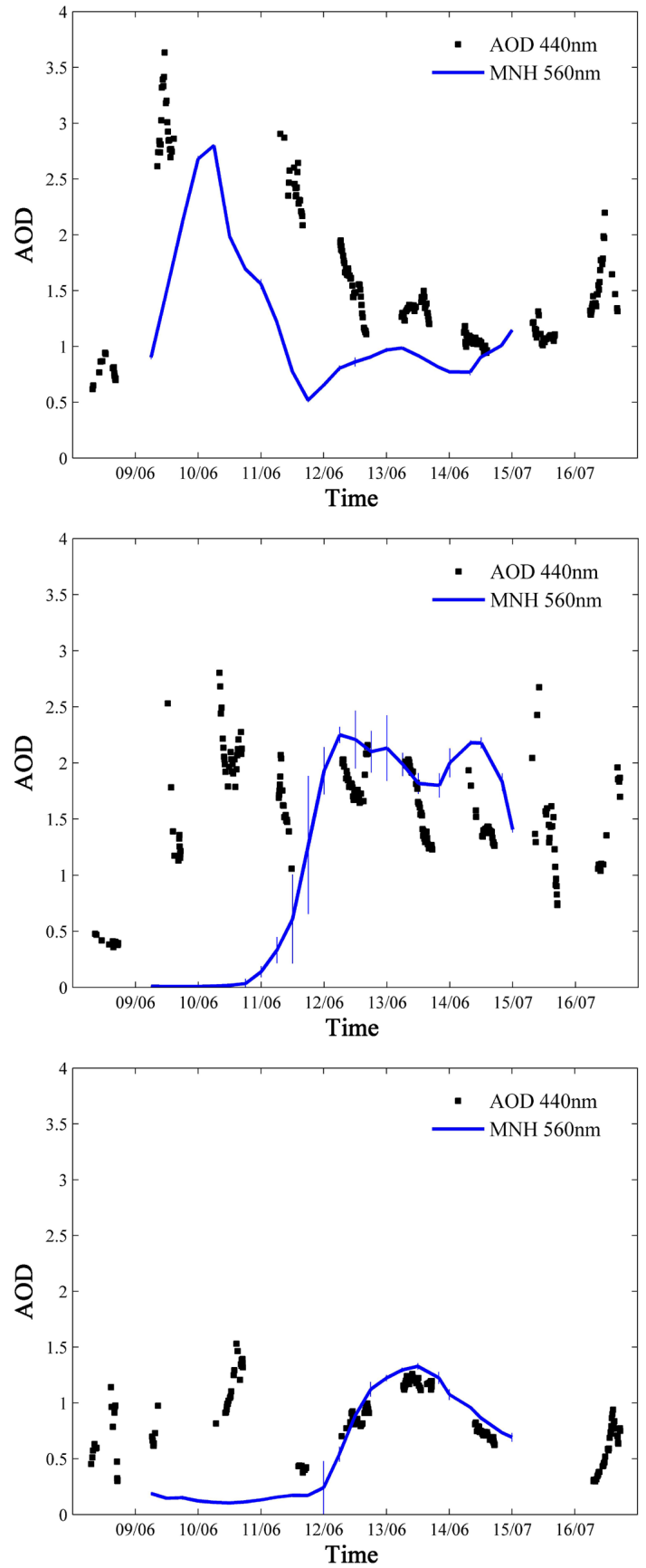

Fig. 4. Aerosol Optical Depth measured from 9 to 16 June 2006 over three Aeronet stations: Maine Soroa, Niger (a), Banizoumbou, Niger (b) and Djougou, Benin (c).

(Flamant et al., 2009a). Figure 3 represents the simulated aerosol optical depth over West Africa during the main dust outbreaks of June. During the AMMA campaign, AERONET photometers were located at Maine Soroa (Niger, $12.02^{\circ} \mathrm{E} / 13.28^{\circ} \mathrm{N}$ ), Banizoumbou (Niger, $2.66^{\circ} \mathrm{E} / 13.54^{\circ} \mathrm{N}$ ) and Djougou (Benin, $1.6^{\circ}$ E/9.76 $\mathrm{N}$ ). In Fig. 3, the observed AOD $(560 \mathrm{~nm})$ is shown in the small boxes to be compared 
to the simulation. Figure 4 represents the time series of simulated and observed AOD at the same stations. The MaineSoroa station is located in the Sahelian region downwind of the lake Chad source area while the two other AERONET stations are located close to big cities (respectively Niamey $13.5^{\circ} \mathrm{N} / 2.2^{\circ} \mathrm{E}$ and Parakou $9.2^{\circ} \mathrm{N} / 2.61^{\circ} \mathrm{E}$ ).

From 9 to 12 June, ECMWF data highlights nocturnal jets (Flamant et al., 2009a) strong enough to lift soil particles by saltation and generate high dust concentration at the surface as simulated by the model (Fig. 3a). Indeed, over the two major sources the AOD is on average about 4. Over the rest of West Africa the AOD is almost zero. On one hand, observed AODs at Maine Soroa seem underestimated by the model but both tendencies are similar (Fig. 4a). On the other hand, simulated AODs at Banizoumbou $\left(\mathrm{AOD}_{\mathrm{obs}}=1.1\right)$ and Djougou $\left(\mathrm{AOD}_{\mathrm{obs}}=0.64\right)$ are largely underestimated $\left(0<\mathrm{AOD}_{\text {sim }}<0.3\right)$ (Fig. $4 \mathrm{~b}$ and c). This underestimation is probably due to pollution and dust particles generated previously which are not taken into account in the simulation.

During the following days, the generated particles are progressively advected westward to the Atlantic Ocean between 9 and 12 June (Fig. 3a, b, c, d). Then, the AOD observed at Banizoumbou and Djougou reaches higher values well represented by the model (for example, 2,1 $\left(\mathrm{AOD}_{\mathrm{obs}}=1.73\right)$ and $0.9\left(\mathrm{AOD}_{\mathrm{obs}}=0.8\right)$ respectively at Banizoumbou and Djougou on the 12 June at 12:00 on Fig. $4 b$ and c). On the 13 and 14 June, the observed AOD in Banizoumbou abruptly decreased during the evening. These tendencies are not simulated and thus the AODs are overestimated during these periods (Fig. 4b). On 13 and 14 June, the AOD tendencies as well as the values are well represented at Djougou (Fig. 4c).

During the period of interest (9-14 June), several Mesoscale Convective Systems (MCS) were triggered over West Africa. The MCS-tracking (Mathon et al., 2002) and the Radagast products (Miller and Slingo, 2007) allowed us to watch the MCS formation and to follow its trajectory along West Africa (data available at the AMMA Operational Center, aoc.amma-international.org/) and to have a dust diagnostic derived from three of the SEVIRI infrared channels (data available http://radagast.nerc-essc.ac.uk/Data.htm) respectively. On 11 June, one massive MCS, initiated over Togo (west of Benin), propagates along the coastline to the Atlantic Ocean. The gust front induced by this MCS and situated in front of the MCS does not involve dust emission at the rear of the MCS (Crumeyrolle et al., 2008), over Benin. On 12 and 13 June, small convective cells appear (over Ilorin and $2^{\circ}$ North of Djougou) but do not generate dust particles at the surface of the continent. Thus, dust particles observed on Fig. 3 over the meridian from Niamey to Cotonou are only a consequence of long range transport from dust sources (Bodélé and Sudan).

The Bodélé and the Sudan are the most important sources of dust particles for this event but the western part of Algeria is also highlighted as a source of dust particles. Indeed, the maximum AOD value is about 2 indicating that the dust concentration lifted up in this zone is weaker than over the main source regions, but not negligible. For comparison, during the intense dust outbreak of 7-13 March 2006, the AOD reached 3.8 and 3.5 at Ilorin (Nigeria) and Banizoumbou, respectively (Tulet et al., 2008).

The aerosol number concentrations measured onboard the ATR-42 with the SMPS and the OPS as a function of altitude during a vertical sounding on 14 June between 15:15 UTC and 15:30 UTC (Fig. 5a) were converted to mass concentrations (Fig. 5b) using a density of $2.5 \mathrm{~g} \mathrm{~cm}^{-3}$ in order to give the mean profile of aerosol mass concentration for the zone considered (i.e. $2^{\circ} \mathrm{E} / 12.6^{\circ} \mathrm{N}$ close to Banizoumbou). These data are compared to the vertical profile of dust number and mass concentration simulated over Banizoumbou on 14 June. The spatial variability ( $1^{\circ}$ around the ATR- 42 sounding area) of the simulated data is represented by the blue area. A size cutoff of $2.5 \mu \mathrm{m}$ was applied to the calculation in order to compare simulated aerosol profiles to airborne observations for particles with diameter lower than $2.5 \mu \mathrm{m}$. The Carbon Monoxide (CO) concentration is used as a tracer to highlight polluted air masses (Fig. 5c, red line). The Angström coefficient (Fig. 5d, black line) is calculated using the scattering coefficients at two wavelengths (450 and $700 \mathrm{~nm}$, Fig. 5d) and depicts the wavelength dependence of the scattering coefficients. Low values of the Angström coefficient highlight low wavelength dependence associated with large particles, i.e. dust particles.

In the boundary layer, between the surface and $1200 \mathrm{~m}$ (Fig. 5b), the observations highlight a well-mixed layer with a steady mass concentration of $20 \mu \mathrm{g} \mathrm{m}^{-3}$. The particle number concentration profile is slightly different and shows a decrease as a function of altitude. Indeed, the number concentration of particles is about $4000 \mathrm{~cm}^{-3}$ at the surface and about $3150 \mathrm{~cm}^{-3}$ at the top of the boundary layer. Furthermore, the simulated dust number and mass concentrations are constant and clearly underestimated in the boundary layer $\left(100 \mathrm{~cm}^{-3}\right.$ and $\left.8 \mu \mathrm{g} \mathrm{m}^{-3}\right)$. This underestimation can be attributed to the simulation's restriction to one type of particle; i.e. dust particles. Actually, the average concentration of CO is significant, about $180 \mathrm{ppb}$, and similar to mean values (200 ppb) found previously over savannah fires (Cofer III et al., 1996). This high CO concentration suggests that a large amount of aerosol particles from local pollution or from biomass burning events are also sampled by the ATR-42. The calculated Angström coefficient value ( 0.35 in average) indicates a mixture of dust and pollution.

The SAL, between 1200 and $3100 \mathrm{~m}$ (Fig. 5b), is characterized by a maximum in the mass particle concentration $\left(32 \mu \mathrm{g} \mathrm{m}^{-3}\right)$ consistent with a previous study (Karyampudi et al., 1999). Moreover, one can note the high concentration and variability of CO (100-180 ppb) in this layer. Between 1200 and $2300 \mathrm{~m}$, the CO concentration slightly decreases with altitude, down to $100 \mathrm{ppb}$, which corresponds to the background concentration of $\mathrm{CO}$ in the upper layer and 

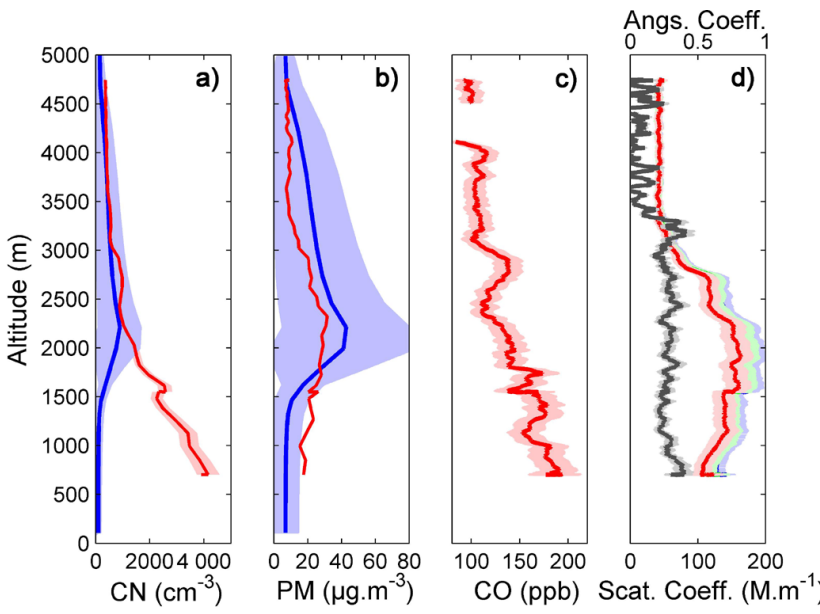

Fig. 5. Profiles of the particle number (a) and mass (b) concentrations at $12.6^{\circ} \mathrm{N}$ and $2^{\circ} \mathrm{E}$ observed by the ATR-42 between 15:15 UTC and 15:30 UTC on 14 June 2006 (red lines) and simulated at 15:00 UTC on 14 June 2006 (blue lines). The blue areas correspond to the spatial variability $\left(1^{\circ}\right.$ around the ATR-42 sounding zone) of dust concentration for particles with diameter lower than $2.5 \mu \mathrm{m}$. Profiles of the $\mathrm{CO}$ concentration (c) and the scattering coefficient (d) at three wavelengths $(450 \mathrm{~nm}, 550 \mathrm{~nm}, 700 \mathrm{~nm}$; respectively blue, green and red lines) observed by the ATR-42 are also plotted. On (d), the black line represents the calculated Angstrom coefficient and the coloured areas correspond to the instrument's internal variability.

in the Northern Hemisphere (Colomb et al., 2006). Since the SAL is decoupled from the surface below and is more closely linked to the desert regions, the $\mathrm{CO}$ concentration and the Angström coefficient highlight that the SAL is subject to strong exchanges with the boundary layer (Parker et al., 2005b). These strong exchanges lead to the presence of different types of particles in the SAL and thus an underestimation of the particle number (66\% on average) concentrations in the simulation. Between 2500 and $3100 \mathrm{~m}$, one can see an increase in the particle number concentrations in the profile $\left(\sim 1000 \mathrm{~cm}^{-3}\right)$ associated with an increase in the $\mathrm{CO}$ concentration which reaches $140 \mathrm{ppb}$. This particular shape is a consequence of long range transport of biomass burning from Central and South Africa. Indeed, the MOPITT data show a plume of $\mathrm{CO}$ coming from the south of West Africa (http://www.acd.ucar.edu/mopitt/MOPITT/data/ plots/maps.html). Thus, in this specific range of altitudes, the simulated concentration is, once again, underestimated $\left(630 \mathrm{~cm}^{-3}\right)$.

Above the SAL is the free troposphere wherein the particle and CO concentrations are, on average, weak $\left(390 \mathrm{~cm}^{-3}\right.$, $8 \mu \mathrm{g} \mathrm{m}^{-3}$ and $100 \mathrm{ppb}$ ). In this layer, the Angström coefficient values are always lower than 0.2 and the main particle type sampled with the ATR- 42 is dust. Thus, the number and mass concentrations are well represented in the simulation $\left(300 \mathrm{~cm}^{-3}, 4 \mu \mathrm{g} \mathrm{m}^{-3}\right)$. Note that while the profile of 14 June

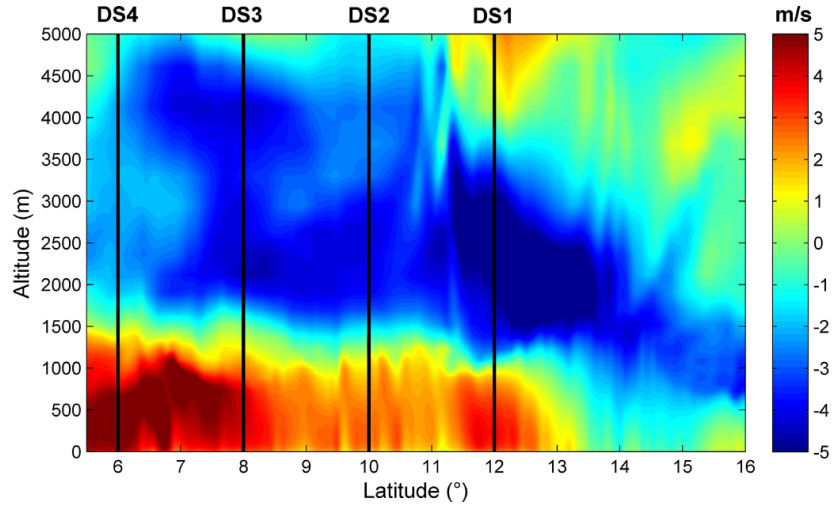

Fig. 6. Vertical cross section (along the ATR-42 flight track at $\left.2.00^{\circ} \mathrm{E}\right)$ of the meridional component of the simulated wind $(\mathrm{m} / \mathrm{s})$. The black lines indicate the location of the dropsondes released by the F-F20 along the transect. The numbers refer to the dropsonde numbers as they appear in Fig. 7.

described in this section was strongly influenced by biomass burning and local pollution, the meridional profile of 13 June was dominated by mineral dust: this earlier flight will be described in the next section.

\subsubsection{Dynamical features}

Figure 6 shows the vertical cross section, along the ATR-42 flight track of the meridional component of the wind velocity $\left(\mathrm{m} \mathrm{s}^{-1}\right)$ simulated by Meso-NH (RAD-SED simulation) at 12:00 UTC on 13 June 2006. This vertical cross section highlights specific dynamical features that occur over West Africa. In the lower layer of the atmosphere $(<1500 \mathrm{~m})$, the meridional wind speed is positive between 6.5 and $13.2^{\circ} \mathrm{N}$ and becomes negative further to the North which depicts the monsoon flux and the Harmattan flux respectively. The monsoon flux is deeper $(1500 \mathrm{~m})$ and stronger $\left(>5 \mathrm{~m} \mathrm{~s}^{-1}\right)$ in the southern part than in the northern part of West Africa as shown previously by Parker et al. (2005a). Above $1500 \mathrm{~m}$ and close to the Inter Tropical Discontinuity (ITD), located at $13.2^{\circ} \mathrm{N}$, the Harmattan flux overrides the monsoon flux and reaches the maximum negative wind speed $\left(<-5 \mathrm{~m} \mathrm{~s}^{-1}\right)$.

The F-F20 flew, in coordination with the ATR-42, between $1.5^{\circ} \mathrm{E} / 15^{\circ} \mathrm{N}$ and $1.5^{\circ} \mathrm{E} / 4^{\circ} \mathrm{N}$ at $8000 \mathrm{~m}$ above mean sea level on the 13 June 2006 (Flamant et al., 2009a). The vertical distribution of atmospheric dynamic and thermodynamic parameters were provided by dropsonde measurements along the meridional transect. Figure 7 shows the evolution of vapour mixing ratio $\left(\mathrm{g} \mathrm{kg}^{-1}\right)$, wind speed $\left(\mathrm{m} \mathrm{s}^{-1}\right)$, wind direction (deg) and potential temperature $(\mathrm{K})$ observed by four dropsondes (DS), whose location is shown in Fig. 6, and simulated by MesoNH. The wind direction and the vapour mixing ratio $(\mathrm{RV})$ profiles depict the dynamical situation shown in Fig. 6, i.e. the Monsoon Layer, with the Harmattan Layer above it. Indeed, between 1000 and $1500 \mathrm{~m}$ altitude, 
a)
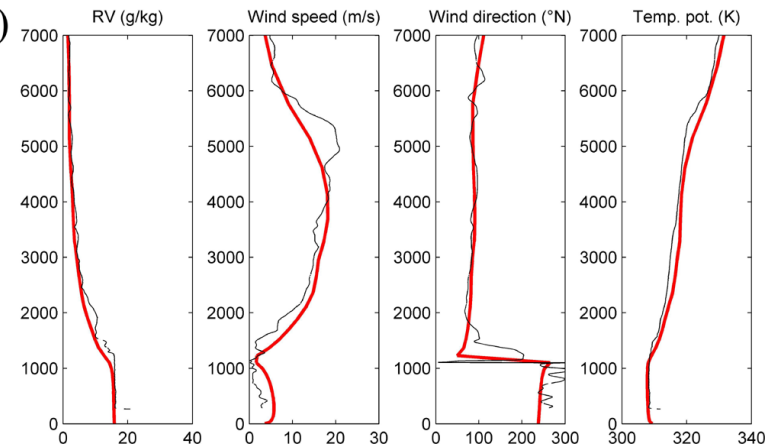

b)
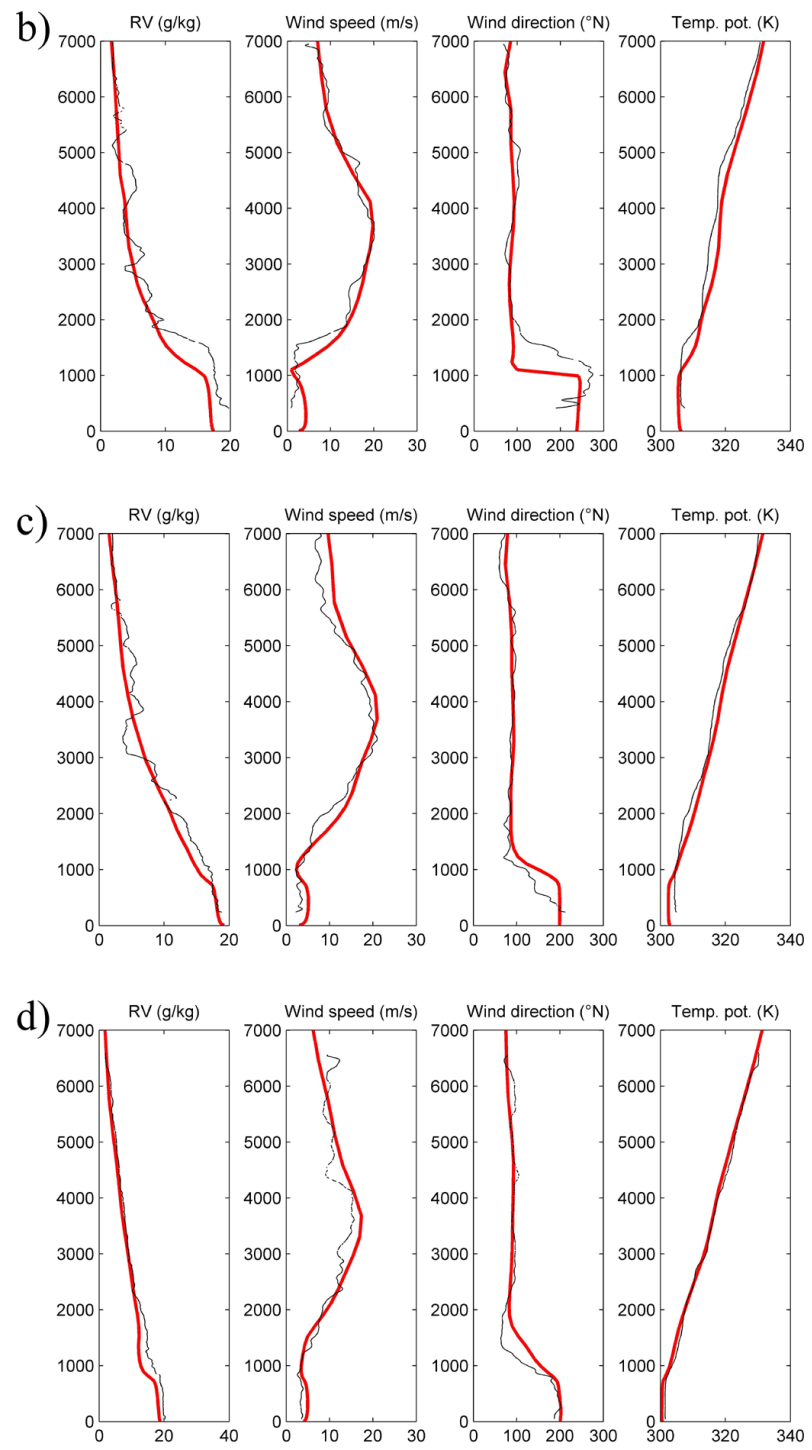

Fig. 7. Vapour mixing ratio $(\mathrm{g} / \mathrm{kg})$, wind speed $(\mathrm{m} / \mathrm{s})$ wind direction (deg) and potential temperature $(\mathrm{K})$ derived from dropsonde measurements (red lines) and the MESONH simulation (black lines) at $12^{\circ} \mathrm{N}(\mathbf{a}, \mathrm{DS} 1)$, at $10^{\circ} \mathrm{N}(\mathbf{b}, \mathrm{DS} 2)$, at $8^{\circ} \mathrm{N}(\mathbf{c}, \mathrm{DS} 3)$ and at $6^{\circ} \mathrm{N}(\mathbf{d}$, DS4) on 13 June. the meridional wind direction changes abruptly from southwesterly (Fig. 7a, b) and southerly (Fig. 7c, d) to easterly and north-easterly, respectively. In the same altitude range, the vapour mixing ratio profile is strongly decreasing which indicates the passage from a humid layer to a dry layer. These key dynamical and thermodynamic parameters are well represented in the simulation, although at $10^{\circ} \mathrm{N}$ (Fig. $7 \mathrm{~b}$ ) the top of the monsoon layer is overestimated by $400 \mathrm{~m}$. As, this inversion height error is not exactly located in the zone of interest $\left(7-9^{\circ} \mathrm{N}\right)$, the simulation results well reproduced the BL dynamics in the southern part of the domain. Moreover, the observed and simulated wind speed profiles are similar; nevertheless, the simulated values are most often underestimated in the monsoon layer $\left(2-4 \mathrm{~m} \mathrm{~s}^{-1}\right)$ as well as in the Harmattan layer $\left(2 \mathrm{~m} \mathrm{~s}^{-1}\right)$. The simulated and observed potential temperature profiles are almost the same for the four soundings.

The above results show that the aerosol optical depth and concentrations as well as the key dynamical and thermodynamic parameters are well represented in the simulation. Thus, the simulation results will be used in the next part to complement and interpret the observations.

\section{Results}

The total number concentration of particles $(\mathrm{CN})$ was first used to characterize the evolution of the aerosol concentration along the meridional flight plan. But, since the electron microscope analysis shows that the majority of dust particles have diameter larger than $0.5 \mu \mathrm{m}$, the concentration of particles with diameter larger than $0.5 \mu \mathrm{m}\left(\mathrm{CN}_{D p>0.5 \mu \mathrm{m}}\right)$ was also used to represent the evolution of dust particles. Since the ATR-42 flew at a constant altitude $(700 \mathrm{~m})$ which was located in the middle of the monsoon layer, the measurements were never carried out within the SAL. Thus, the evolution of dust particle concentrations was only studied in the monsoon layer where its presence may be explained by the sedimentation process from the SAL or by a local generation. Then, the temperature gradient, the potential temperature, the surface temperature, the meridional wind velocity and the percent of forest/shrub cover were used to find out the link between the surface cover and the dynamics in the boundary layer (Fig. 9). Afterwards, the simulation results were analysed in the same manner.

\subsection{Observations of sedimentation and entrainment processes}

Figure 8a shows the evolution of $\mathrm{CN}$ and of $\mathrm{CN}_{D p>0.5 \mu \mathrm{m}}$ concentrations measured as a function of latitude during the flight from Niamey $\left(13.51^{\circ} \mathrm{N}\right)$ to Cotonou $\left(6.36^{\circ} \mathrm{N}\right)$ between 10:30 UTC and 13:30 UTC on 13 June, while Figure $8 \mathrm{~b}$ shows the evolution of the Angström coefficient during the same flight. In the northern part of the domain, the tendencies 

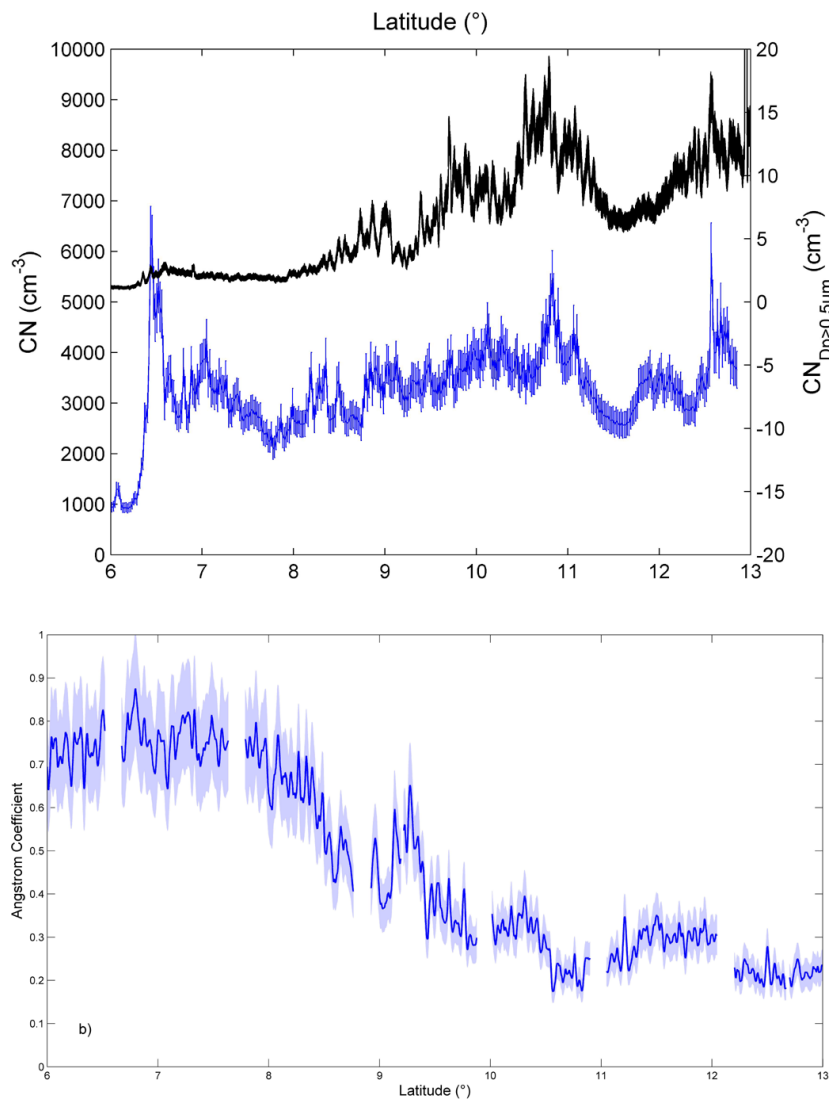

Fig. 8. (a) Total particle concentration (blue line) measured onboard the ATR-42 on 13 June between 10:30 UTC and 13:30 UTC as a function of latitude. Concentration of particles with diameter larger than $0.5 \mu \mathrm{m}$ is also plotted (in grey) as a function of latitude. The red rectangle denotes the zone where the dust content is maximum. (b) The Angstrom coefficient calculated from scattering coefficients is represented by the blue line. The light blue area corresponds to the error bar including uncertainty in the measurements of scattering coefficients and propagation of errors during calculations.

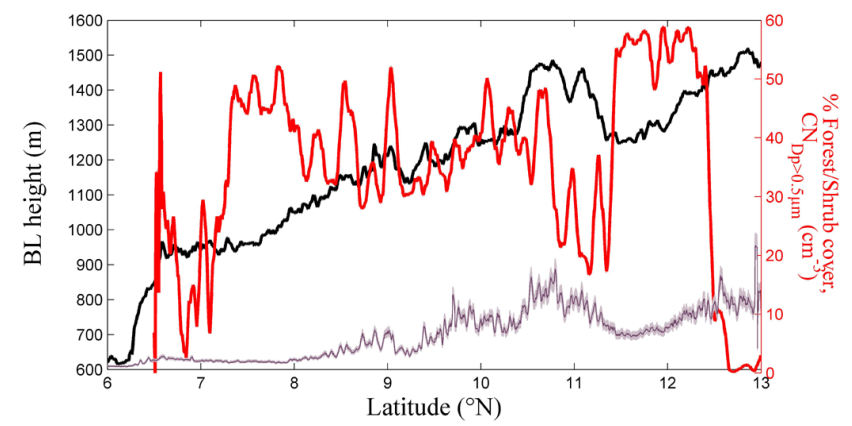

Fig. 9. Calculated boundary layer top (black line) at 12:00 UTC on 13 June and fraction of forest/shrub cover as derived from the GlobCover Land Cover map (red line) as a function of latitude. of the $\mathrm{CN}$ and $\mathrm{CN}_{D p>0.5 \mu \mathrm{m}}$ concentrations are similar. At the beginning of the flight (North), the total particle concentration is high and reaches $6000 \mathrm{~cm}^{-3}$ at $12.6^{\circ} \mathrm{N}$. In the same area, the concentration of dust particles $\left(\mathrm{CN}_{D p>0.5 \mu \mathrm{m}}\right)$ also reaches a maximum $\left(16 \mathrm{~cm}^{-3}\right)$ and the relative low value of the calculated Angström coefficient (0.2), indicating few wavelength dependence of the scattering coefficient, confirms the presence of a mode of coarse dust particles in the sampled layer.

Moving southward, the $\mathrm{CN}$ as well as $\mathrm{CN}_{D p>0.5 \mu \mathrm{m}}$ concentrations decrease up to a first minimum (respectively 2500 and $6.5 \mathrm{~cm}^{-3}$ ) at $11.5^{\circ} \mathrm{N}$. In this area the surface cover is sufficient to inhibit the local production of dust particles (Flamant et al., 2007, 2009a) which seems to be consistent with the decrease of $\mathrm{CN}_{D p>0.5 \mu \mathrm{m}}$ concentration. At $10.8^{\circ} \mathrm{N}$, the $\mathrm{CN}$ as well as the $\mathrm{CN}_{D p>0.5 \mu \mathrm{m}}$ concentrations reach a second maximum (respectively 5500 and $17 \mathrm{~cm}^{-3}$ ) associated with a second minimum of the Angström coefficient (0.2). Nonetheless, in this area the vegetation cover (0.2, see Fig. 9) is still too important to allow local dust production (Kimura et al., 2009). Indeed, the maximum value of the $\mathrm{CN}_{D p>0.5 \mu \mathrm{m}}$ concentrations measured at the super-site of Djougou during the period of interest is about $3 \mathrm{~cm}^{-3}$ on 14 June. These measurements confirm that dust particles observed with the ATR-42 are not generated at the surface but their presence in this zone is only due to long range transport from the northern region.

South of $10^{\circ} \mathrm{N}$, the $\mathrm{CN}_{D p>0.5 \mu \mathrm{m}}$ concentration decreases with latitude while the $\mathrm{CN}$ concentration reaches a third maximum at $6.5^{\circ} \mathrm{N}$ (close to the gulf of Guinea) due to the presence of a pollution plume originating from anthropogenic activities near Cotonou. This result is confirmed by higher values of the Angstrom coefficient (0.8). Generally, between $6^{\circ} \mathrm{N}$ and $10^{\circ} \mathrm{N}$, particles from polluted or biomass-burning zones are more dominant.

Recent studies investigated the impact of soil moisture and vegetation heterogeneities on the dynamics within the planetary boundary layer (Taylor et al., 2003, 2007; GarciaCarreras et al., 2010). Moreover, Garcia-Carreras study highlighted a strong relationship between the boundary layer temperatures, the boundary layer top, the meridional wind velocity and the fraction of forest or shrub cover. This study, which covers a region overlapping with this one, found that Bowen ratio and its impact on the sensible heat fluxes was the dominant mechanism via which the surface controlled boundary layer temperatures, as opposed to either roughness or albedo, with higher temperatures over the crop leading to increased boundary layer heights compared to adjacent forest. The boundary layer temperature anomalies caused by variations in sensible heat flux or Bowen ratio at boundaries between forest/shrub and cropland lead to an increase in the boundary layer top. The vertical distribution of dynamic and thermodynamic quantities, which were used to estimate the BL height, were documented using dropsonde 
measurements. As the ATR-42 flew before the F-F20, the boundary layer height can therefore be expected to have increased during the delay between both aircraft passage due to the evolution of the surface heat fluxes and the resultant entrainment of residual-layer air. Thus, the BL height has been estimated using the method described in Hopkins et al. (2009). This method is based on the fact that the temperature and depth of a convective boundary layer are related to the stratification above the boundary layer top : if we assume that this stratification is relatively invariant with position, then boundary layer depth are directly related to the mixed-layer temperature. Figure 9 shows the calculated boundary layer height and the amount of forest/shrub cover derived from the GlobCover Land Cover map as in GarciaCarreras et al. (2010) along the meridian from Niamey to Cotonou. The BL height increases suddenly at $6.3^{\circ} \mathrm{N}$, corresponding to the passage over the coastline, and slightly increases from $950 \mathrm{~m}\left(6.6^{\circ} \mathrm{N}\right)$ to $1250 \mathrm{~m}\left(9.9^{\circ} \mathrm{N}\right)$. In the same latitude range, the forest/shrub cover increases abruptly at $7.1^{\circ} \mathrm{N}(>50 \%)$ and then becomes stable (35\%). Over the area running from $9.9^{\circ} \mathrm{N}$ to $12.3^{\circ} \mathrm{N}$, the forest/shrub cover diminishes $(15 \%)$ from $9.9^{\circ} \mathrm{N}$ to $11.1^{\circ} \mathrm{N}$, and as a consequence of an increase in Bowen ratio, the surface temperature increases. Thus, the BL height reaches maximum values $(1500 \mathrm{~m})$. These results show a strong relationship between surface cover and the height of the boundary layer (as inferred from BL temperature), consistent with the results of Garcia-Carreras et al. (2010) from flights later in the season. This coupling between the surface and the boundary layer dynamics occurs exactly in the same area of high dust content.

Garcia-Carreras et al. (2010) show that the vegetation anomalies are related to the vertical transport of isoprene from the surface to the upper layers, thus, amplifying exchanges between the monsoon flux (high content of isoprene/low content of dust particles) and the Harmattan layer (low content of isoprene/high content of dust particles). In this case, the growth of the BL leads to entrainment of dusty air from the upper layer (SAL) into the BL. Thus, the vegetation anomalies are associated to the presence of high concentrations of dust particles in the monsoon flux. To complement the observations and interpret the results, a simulation exercise was carried out.

\subsection{Numerical modelling: sedimentation and entrainment quantification}

Two separate simulations have been done, one which takes into account the dust sedimentation (SED) and another one which does not take into account the dust sedimentation (NOSED). In the following part, the dust radiative impact has been turned off, in order to have similar atmospheric dynamics in both simulations (NORAD). Thus, the only variable differing between both simulations is the dust sedimentation. The vertical cross-section of dust number concentra-

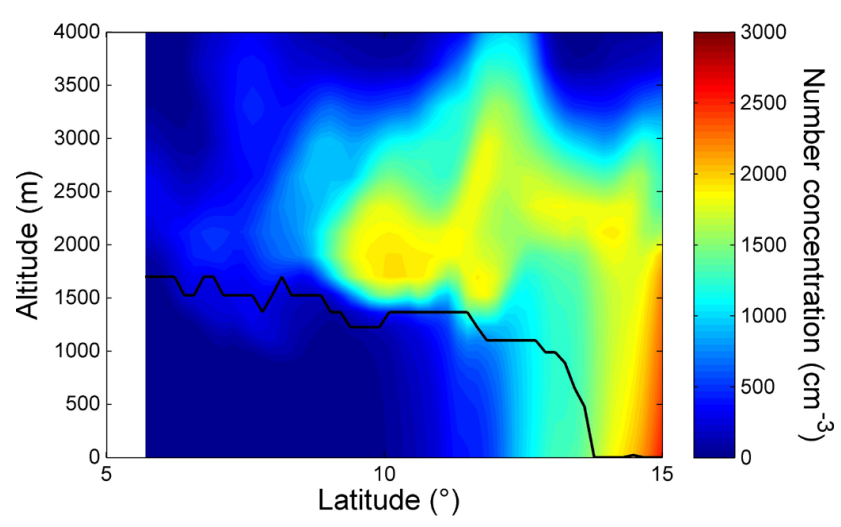

Fig. 10. Cross-section of dust number concentration for the simulation including sedimentation (NORAD-SED) at 12:00 UTC on 13 June. The black line illustrates the top of the monsoon flux.

tion of the SED simulation is given in Fig. 10. The northern part of the domain, which corresponds to an arid region of sparse vegetation, is subjected to strong low level winds at the surface and numerous dust particles $\left(3000 \mathrm{~cm}^{-3}\right)$ are produced in this region. These freshly generated particles are then transported in a south-westward direction within the Harmattan flux over the monsoon flux. Both layers, the monsoon flux and the SAL, are clearly distinguished using the dust concentration gradient. Indeed, the dust particle concentration is lower than $500 \mathrm{~cm}^{-3}$ in the monsoon layer (excluding the ITD region $\left(13.2^{\circ} \mathrm{N}\right)$ where dust particles are carried away by turbulence in the monsoon flux; Bou Karam et al., 2008) and on average about $1500 \mathrm{~cm}^{-3}$ in the SAL.

Figure 11 shows the evolution of the dust mass size distribution as a function of launched sonde latitudes for both simulations SED and NOSED (line and dashed line, respectively). For the NOSED simulation, the amplitude for the coarse mode decreases with latitude due to diffusion of dust particles during their transport, while for the SED simulation the evolution of size distributions shows a decrease of the amplitude of the coarse mode up to $10^{\circ} \mathrm{N}$ and then an increase due to the sedimentation process of dust particles from upper layers. The comparison of dust particle size distributions of both simulations (SED/NOSED) gives the quantity of sedimented dust for each mode and at each latitude. At $12^{\circ} \mathrm{N}$, about $50 \%$ of the mass of larger dust particle has sedimented while the sedimentation process leads to an increase of only $2 \%$ of the mass of particles forming the medium mode of Table 1. By the time air reaches the southern part of the section, at $6^{\circ} \mathrm{N}$, more than $85 \%$ of particles of the coarse mode and about $10 \%$ of those of the medium mode have sedimented. In terms of particle number concentrations, this sedimentation process leads to a gain of about 100 particles, corresponding to a mass concentration of $3600 \mu \mathrm{g} \mathrm{m}^{-3}$ at $2000 \mathrm{~m}$. The sedimentation process of dust particles is thus two times more efficient in the southern part of the domain than close to source regions. 


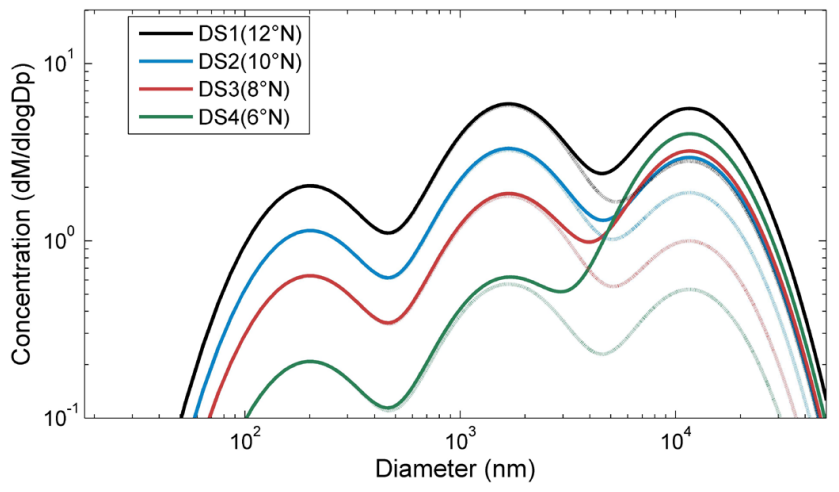

Fig. 11. Mass size distribution for the SED simulation (line) and the NOSED simulation (dashed line) of dust particles transported in the Saharan Air Layer (SAL), at $2000 \mathrm{~m}$, for different latitudes $\left(12^{\circ} \mathrm{N}\right.$, $10^{\circ} \mathrm{N}, 8^{\circ} \mathrm{N}, 6^{\circ} \mathrm{N}$ ) at 12:00 UTC on 13 June.

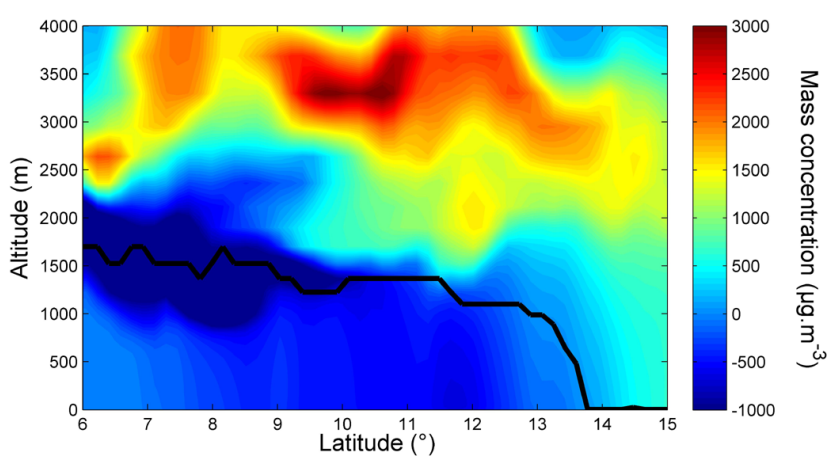

Fig. 12. Difference of dust mass concentration between the simulation without sedimentation (NOSED) and the simulation including sedimentation (SED; see text for more details) at 12:00 UTC on 13 June. Negative mass concentrations correspond to sedimented particles. The black line illustrates the top of the monsoon flux.

In order to have a general view of the dust particle sedimentation process, the difference of dust mass concentrations between the simulation without sedimentation and the simulation including sedimentation (NOSED-SED) is given in Fig. 12. Negative mass concentrations correspond to sedimented particles and positive concentrations correspond to dust particles that are removed because of the sedimentation process. The top of the monsoon flux, marked with the black line (Fig. 12), has been delineated using the method given by Lamb (1983). Between $6^{\circ} \mathrm{N}$ and $9^{\circ} \mathrm{N}$, the difference of dust concentration is minimum $\left(\sim-1000 \mathrm{~cm}^{-3}\right)$ in both the monsoon layer and the Harmattan layer. These particles are mainly coming from upper layers where the difference in dust concentrations is maximum (layer at $3500 \mathrm{~m}$ ). Furthermore, this sedimentation process leads to the presence of dust in the boundary layer down to $800 \mathrm{~m}$, corresponding to the higher altitude of the ATR-42 flight plan, between $7.3^{\circ} \mathrm{N}$ and $8.8^{\circ} \mathrm{N}$.
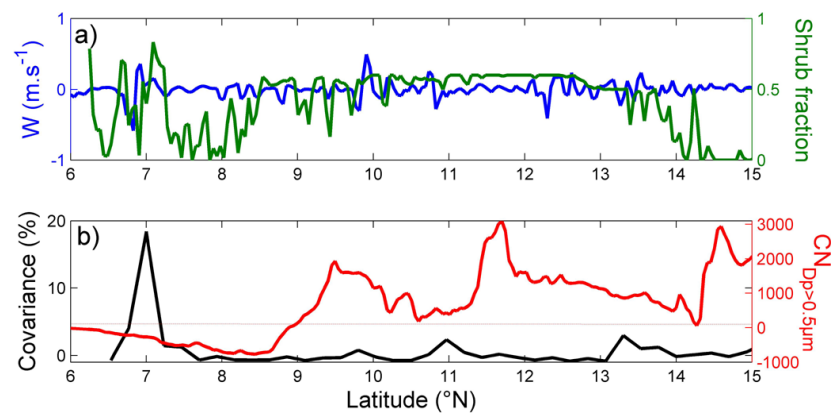

Fig. 13. (a) Difference of vertical wind speed (blue line) between the initial simulation (ECOCLIMAP I, VAR) and the simulation including surface cover modifications (C30) and Shrub fraction cover of ECOCLIMAP-I (green line). (b) Covariance (black line), in percent, between both tendencies (shown in a) and CNDp $>0.5 \mu \mathrm{m}$ (at $1000 \mathrm{~m}$ ) concentration as a function of latitude at 12:00 UTC on 13 June.

The comparison of Figs. 8 and 12 highlights some differences in the latitude range where the maximum dust concentration is located. To understand why there is this discrepancy between simulation results and observations, the surface cover has to be studied. Indeed, the fraction of forest/shrub cover used in the simulation is an ECOCLIMAP climatology with $1 \mathrm{~km}$ of resolution (Fig. 13a). ECOCLIMAP-I corresponds to the period 1992-1993 using 1-km re-sampled datasets from the Advanced Very High Resolution Radiometer (AVHRR) instrument. Natural ecosystems typically vary on a decadal basis and therefore ECOCLIMAP-I is likely to be valid for the $90 \mathrm{~s}$. Updating ECOCLIMAP-I into ECOCLIMAP-II land cover map over West Africa is now performed on the basis of observations from MODIS (Kaptue et al., 2010). Unfortunately, the upgraded climatology is not yet operational with the version of the mesoscale model used in this study. Thus, the comparison with another climatology, Globcover Land Cover map, with higher resolution (300m, Figure 9b) highlights some inconsistencies. Indeed, the forest/shrub cover is much more important (30\%) between $6^{\circ} \mathrm{N}$ and $7^{\circ} \mathrm{N}$ in ECOCLIMAP-I than the Globcover surface cover and clearly weaker $(20 \%)$ between $7^{\circ} \mathrm{N}$ and $8^{\circ} \mathrm{N}$ (Fig. 13a). In the northern part of the domain, the ECOCLIMAP-I forest/shrub cover is always higher than $40 \%$ and frequently exceeds $55 \%$. As a result, the surface cover anomalies are located in the southern part of the domain, leading to weaker heat flux and lower top of the boundary layer.

The comparison between observation and simulation results seems to show that the presence of vegetation anomalies and dust entrainment from the SAL into the BL are closely linked. To highlight this relationship, a new set of simulations has been done using a manually modified surface cover and has been compared to the previous ones using ECOCLIMAP-I surface cover. Indeed, all the vegetation 


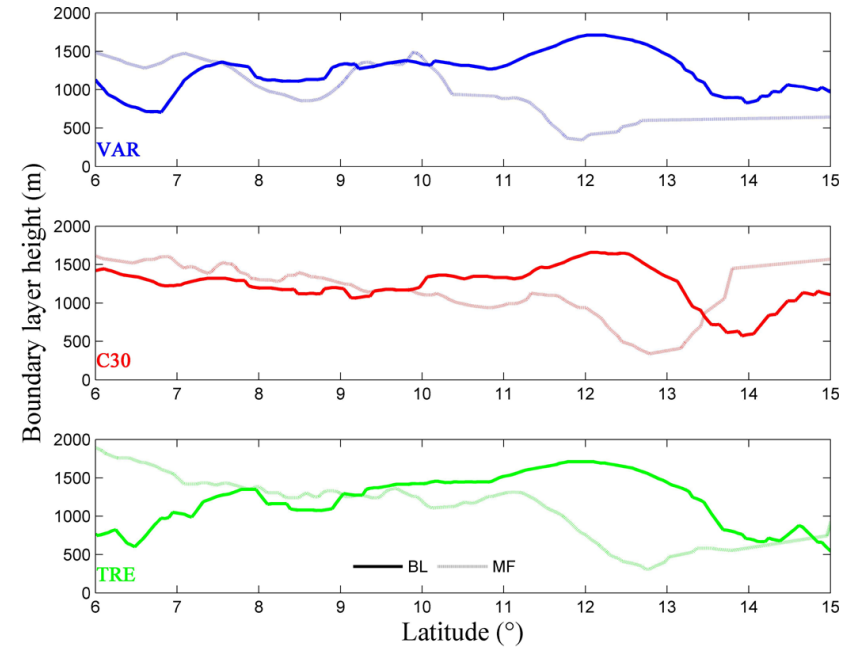

Fig. 14. Height of the boundary layer (BL, solid line) and the monsoon flux (MF, dashed line) as a function of latitude for three simulation runs on 13 June 2006 12:00 UTC. VAR: variable vegetation cover, C30: constant surface cover of cropland, TRE: constant surface cover of tree.

type defined in the model, except the bare soil, are changed to crop (C30) or in forest (TRE). Figure 13a represents the shrub fraction from ECOCLIMAP I along the ATR flight track together with the difference of vertical wind speed between the initial simulation (ECOCLIMAP I, VAR) and the simulation including surface cover modifications (C30). The shrub cover maximum heterogeneity occurs between 6.5 and $7.5^{\circ} \mathrm{N}$ exactly in the same zone where the maximum amplitude of the $\Delta \mathrm{W}$ is observed. Moreover, in this specific area the covariance values are highest which implies that both parameters are not independent from each other. The same conclusions could be made regarding the meridional and zonal wind speeds.

The height of the boundary layer has been defined using the turbulent kinetic energy (TKE) criterion for simulation using different version of surface cover (Fig. 14). The TKE is minimum at the interface between the PBL and the troposphere (Stull, 1988). As the boundary layer height values in case of constant surface cover is not representative of the reality, only the trend of each curve will be compared. Looking only at PBL fluctuations, two regions may be distinguished: the northern part of the domain $\left(10-15^{\circ} \mathrm{N}\right)$ and the southern part of the domain $\left(6-9^{\circ} \mathrm{N}\right)$. In the Northern part, the height of the boundary layer is similar for the VAR and C30 simulation while TRE simulation results are different between 13$15^{\circ} \mathrm{N}$. This is probably a consequence of the more intense water exchange over forest than for other types of vegetation. In the southern part of the domain, the boundary layer height shows clearly a different tendency for VAR simulation results than for the two others. Indeed a strong increase is observed at $7^{\circ} \mathrm{N}$ (heterogeneity area) as opposed to the PBL for the constant surface cover simulations, which remains more or less constant. Thus, this figure is highlighting a clear effect of surface cover heterogeneities on the PBL dynamics and therefore on the dust sedimentation.

The difference of dust particle concentration at $1000 \mathrm{~m}$ between the simulation using fixed soil cover and the simulation using ECOCLIMAP data is represented in Fig. 13b. Negative concentrations correspond to particles which are present in the boundary layer in case of surface heterogeneities and not present in case of constant soil cover. One can see that the concentrations are negative in an area running from 6.5 to $9^{\circ} \mathrm{N}$, exactly where the surface heterogeneities are located. As no dust outbreaks have been observed in the simulation between Niamey and Cotonou, these dust particles are coming from long range transport by the Harmattan flux.

Finally, the comparison between observation and simulation results shows that the presence of vegetation anomalies and dust are closely linked. Indeed, a reduction in forest or shrub cover leads to an increase in the BL height (inferred from BL temperature in the observations, and consistent with the model results) and leads to exchanges between the monsoon layer and the Harmattan layer via entrainment. Thus, aerosol particles and compounds produced in the monsoon layer are measured in the upper layer (Garcia-Carreras et al., 2010) while aerosol particles transported from desert regions by the Harmattan flux are observed in the monsoon layer. These mechanisms imply that we should infer a significant diurnal cycle in the mechanisms of dust sedimentation from the SAL to the monsoon layer. During the day, the sedimentation is modulated by the differing rates of BL entrainment over differing surfaces. At night, when the atmospheric profile is more stable (Parker et al., 2005b), sedimentation acts alone and is likely to be independent of the underlying surface.

\section{Conclusion}

This paper describes the impact of vegetation anomalies on mineral dust particle sedimentation and entrainment observed during the AMMA experiment by using a combination of airborne observations and simulation exercises. Airborne measurements of aerosol characteristics were carried out along a meridian from Niamey (Niger) to Cotonou (Benin) on 13 and 14 June 2006. The measurements were performed by two aircrafts (ATR-42 and F-F20) flying on the same meridian at two different altitudes $(700 \mathrm{~m}$ and $8000 \mathrm{mg}$, respectively). Observations were then interpreted using a mesoscale model simulation in order to explain the presence of high dust content over an area where local production is strongly inhibited by the surface cover.

The ATR-42 observations highlight that the boundary layer temperature is linked with the surface cover, which produces a strong relationship with the dust particle concentrations in the boundary layer. Consistent with model 
simulations, we infer that the relationship between dust particle concentration and BL temperature occurs due to the deepening of the BL over warmer surfaces, by entrainment. Indeed, the optical particle sizer (OPS GRIMM) and the nephelometer measurements show the presence of mineral dust particles highly concentrated between $10^{\circ} \mathrm{N}-11.7^{\circ} \mathrm{N}$. As local emissions are inhibited in this zone, these particles are coming from long range transport within the SAL and sedimentation and entrainment processes in the boundary layer. This zone of high dust content is slightly shifted to the North due to the general circulation over West Africa (monsoon winds).

Particle size distributions observed close to the source region $\left(>15^{\circ} \mathrm{N}\right.$ and $\left.>4.5^{\circ} \mathrm{E}\right)$ have been used to improve the dust size spectrum parameterization. This new dust parametrisation implemented in Meso-NH allows the model to better represent the number and mass distributions of dust particles. The comparison of few simulations with different surface cover highlights, as in the observations, an increase of the boundary layer top induced by vegetation anomalies but closer from the coastline $\left(7^{\circ} \mathrm{N}-8^{\circ} \mathrm{N}\right)$. Indeed, the surface cover used in Meso-NH is an ECOCLIMAP climatology with a resolution of $1 \mathrm{~km}$ and is not the same as the GlobCover Land Cover map products (resolution $300 \mathrm{~m}$ ). Finally, two mesoscale simulation exercises have been done to complement these results, one simulation with dust particle sedimentation (SED) and the other one without dust sedimentation (NOSED). The comparison of SED and NOSED simulations quantifies the concentration of dust particles which sediment, and the location of this process. The sedimentation process leads to the vertical transport of dust particles $\left(1000 \mu \mathrm{g} \mathrm{m}^{-3}\right)$ from the Harmattan layer (or SAL) to the monsoon layer between $6^{\circ} \mathrm{N}$ and $9^{\circ} \mathrm{N}$. This mechanism may involve deep vertical transport (up to $800 \mathrm{~m}$ ) of dust particles in the monsoon layer, between $7.3^{\circ} \mathrm{N}$ and $8.8^{\circ} \mathrm{N}$. Thus, the comparison results confirm how the sedimentation and entrainment processes are linked with the mesoscale vegetation anomalies observed in the region.

Acknowledgements. This work has been supported by the African monsoon multidisciplinary analysis (AMMA) project. Based on a French initiative, AMMA was built by an international scientific group and is currently funded by a large number of agencies, especially from France, UK, USA and Africa. The authors wish to thank the SAFIRE (Service des Avions Francais Instruments pour la Recherche en Environnement) for preparing and delivering the research aircrafts (ATR-42 and Falcon-20). The authors are grateful to the MesoNH team for their assistance. Suzanne Crumeyrolle has been supported by CNRS fellowship (contract no. 167641). Luis Garcia-Carreras has been supported by NERC studentship NE/F007477/1. AMMA-UK is supported by NERC grant NE/B505538/1. Special thanks to P. Peyrillé, A. Boone and L. Kergoat for the discussion on surface cover.

Edited by: C. Reeves

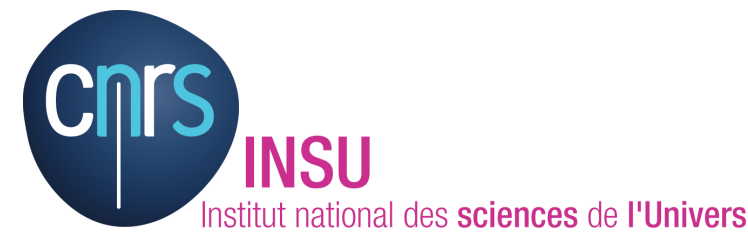

The publication of this article is financed by CNRS-INSU.

\section{References}

Alfaro, S. C. and Gomes, L.: Modeling mineral aerosol production by wind erosion: Emission intensities and aerosol size distributions in source areas, J. Geophys. Res., 106(D16), 18075-18084, 2001.

Albrecht, B. A.: Aerosols, cloud microphysics, and fractional cloudiness. Science, 245, 1227-1230, 1989.

Avila, A., Queralt-Mitjans, I., and Alarcon, M.: Mineralogical composition of African dust delivered by red rains over the northeastern Spain, J. Geophys. Res., 102, 21977-21996, 1997.

Barthe, C., Molinie, G., and Pinty, J. P.: Description and first results of an explicit electrical scheme in a $3 \mathrm{~d}$ cloud resolving model, Atmos. Res., 76(1-4), 95-113, 2005.

Bechtold, P., Bazile, E., Guichard, F., Mascart, P., and Richard, E.: A mass-flux convection scheme for regional and global models, Q. J. Roy. Meteorol. Soc., 127, 869-886, 2001.

Boone, A., De Rosnay, P., Balsamo, G., Beljaars, A., Chopin, F., Decharme, B., Delire, C., Ducharne, A., Gascoin, S., Grippa, M., Guichard, F., Gusev, Y., Harris, P., Jarlan, L., Kergoat, L., Mougin, E., Nasonova, O., Norgaard, A., Orgeval, T., Ottl, C., Poccard-Leclerq, I., Polcher, J., Sandholt, I., Saux-Picart, S., Taylor, C., and Xue, Y.: The AMMA Land Surface Model Intercomparison Project (ALMIP), B. Am. Meteorol. Soc., 18651880, doi:10.1175/2009BAMS2786.1, 2009.

Bougeault, P. and Lacarrére, P.: Parametrization of orographyinduced turbulence in a mesobeta model, Mon. Weather Rev., 117, 1872-1890, 1989.

Bou Karam, D., Flamant, C., Tulet, P., Todd, M. C., Pelon, J., and Williams, E.: Dry cyclogenesis and dust mobilization in the Inter Tropical Discontinuity of the West African Monsoon: a case study, J. Geophys. Res., 114, D05115, doi:10.1029/2008JD010952, 2008.

Cofer III, W. R., Levine, J. S., Winstead, E. L., Cahoon, D. R., Sebacher, D. I., Pinto, J. P., and Stocks, B. J.: Source compositions of trace gases released during African savanna fires, J. Geophys. Res., 101(D19), 23597-23602, 1996.

Colomb, A., Williams, J., Crowley, J., Gros, V., Hofmann, R., Salisbury, G., Klüpfel, T., Kormann, R., Stickler, A., Forster, and C., Lelieveld, J.: Airborne Measurements of Trace Organic Species in the Upper Troposphere Over Europe: the Impact of Deep Convection, Environ. Chem., 3, 244-259, 2006.

Cohard, J. M. and Pinty, J. P.: A comprehensive two-moment warm microphysical bulk scheme, ii: $2 \mathrm{~d}$ experiments with a non hydrostatic model, Q. J. Roy. Meteorol. Soc., 126, 1843-1859, 2000.

Crumeyrolle, S., Gomes, L., Tulet, P., Matsuki, A., Schwarzenboeck, A., and Crahan, K.: Increase of the aerosol hygroscopicity by cloud processing in a mesoscale convective system: a case study from the AMMA campaign, Atmos. Chem. Phys., 8, 69076924, doi:10.5194/acp-8-6907-2008, 2008. 
Cuesta, J., Marsham, J. H., Parker, D. J., and Flamant, C.: Dynamical mechanisms controlling the vertical redistribution of dust and the thermodynamic structure of the West Saharan atmospheric boundary layer during summer, Atmos. Sci. Lett., 10, 34-42, doi:10.1002/asl.207, 2009.

De Rosnay, P., Drusch, M., Boone, A., Balsamo, G., Decharme, B., Harris, P., Kerr, Y., Pellarin, T., Polcher, J., and Wigneron, J.-P.: AMMA Land Surface Model Intercomparison Experiment coupled to the Community Microwave Emission Model: ALMIP-MEM, J. of Geophys. Res., 114, D05108, doi:10.1029/2008JD010724, 2009.

Filippi, D.: Etude et développement d'un instrument aéroporté destiné à la collecte des aérosols et à la mesure du Radon 222 par son dépôt actif, thèse Univ. Paris VI, 267 pp., 2000.

Flamant, C., Chaboureau, J.-P., Parker, D. J., Taylor, C. M., Cammas, J.-P., Bock, O., Timouck, F., and Pelon, J.: Airborne observations of the impact of a convective system on the planetary boundary layer thermodynamics and aerosol distribution in the inter-tropical discontinuity region of the west african monsoon, Q. J. Roy. Meteorol. Soc., 133, 1175-1189, 2007.

Flamant, C., Lavaysse, C., Todd, M. C., Chaboureau, J.-P., and Pelon, J.: Multi-platform observations of a springtime case of Bodélé and Sudan dust emission, transport and scavenging over West Africa, Q. J. Roy. Meteorol. Soc., 135(639), 413-430, 2009a.

Flamant, C., Knippertz, P., Parker, D., Chaboureau, J.-P., Lavaysse, C., Agusti-Panareda, A., and Kergoat, L.: The impact of a mesoscale convective system cold-pool on the northward propagation of the inter-tropical discontinuity over West Africa, Q. J. Roy. Meteorol. Soc., 135, 139-165, 2009 b.

Formenti, P., Grand, N., Chevaillier, S., Schmechtig, C., and Desboeufs, K.: Airborne observations of aerosol particles over western Africa in the summer Monsoon season: spatial and vertical variability of physico-chemical and optical properties, Atmos. Chem. Phys., in preparation, 2010.

Garcia-Carrerasf, L., Parker, D. J., Taylor, C. M., Reeves, C. E., and Murphy, J. G.: Impact of mesoscale vegetation heterogeneities on the dynamical and thermodynamic properties of the planetary boundary layer, J. Geophys. Res., 115, D03102, doi:10.1029/2009JD012811, 2010.

Ginoux, P., Chin, M., Tegen, I., Prospero, J. M., Holben, B. N., Dubovik, O., and Lin, S.-J.: Sources and distribution of dust aerosols with the GOCART model, J. Geophys. Res., 106(D17), 20255-20273, 2001.

Gobbi, G. P., Barnaba, F., Van Dingenen, R., Putaud, J. P., Mircea, M., and Facchini, M. C.: Lidar and in situ observations of continental and Saharan aerosol: closure analysis of particles optical and physical properties, Atmos. Chem. Phys., 3, 21612172, doi:10.5194/acp-3-2161-2003, 2003.

Goudie, A. S. and Middleton, N. J.: Saharan dust storms: nature and consequences, Earth-Sci. Rev., 56(1), 179-204, 2001.

Grini, A., Myhre, G., Sundet, J. K., and Isaksen, I. S. A.: Modeling the annual cycle of sea salt in the global 3-D model Oslo CTM-2, J. Climate, 15, 1717-1730, doi:10.1175/15200442(2002)015; 1717:MTACOS $i 2.0 . C O ; 2,2002$.

Grini, A., and C. S. Zender, Roles of saltation, sandblasting, and wind speed variability on mineral dust aerosol size distribution during the Puerto Rican Dust Experiment (PRIDE), J. Geophys. Res., 109(D7), D07202, doi:10.1029/2003JD004233, 2004.
Grini, A., Tulet, P., and Gomes, L.: Dusty weather forecasts using the MesoNH mesoscale atmospheric model, J. Geophys. Res., 111, D19205, doi:10.1029/2005JD007007, 2006.

Guerzoni, S., Molinaroli, E., and Chester, R.: Saharan dust inputs to the western Mediterranean Sea: depositional patterns, geochemistry and sedimentological implications, Deep-Sea Res. II, 44(3-4), 631-654, 1997.

Hopkins J. R., Evans, M. J., Lee, J. D., Lewis, A. C., Marsham, J. H., McQuaid, J. B., Parker, D. J., Stewart, D. J., Reeves, C. E., and Purvis, R. M.: Direct estimates of emissions from the megacity of Lagos, Atmos. Chem. Phys., 9, 84718477, doi:10.5194/acp-9-8471-2009, 2009.

Houghton, J. T., Ding, Y., Griggs, D. J., Noguer, M., Van der Linden, P. J., and Xiaosu, D. (Eds.): Climate Change 2001: The Scientific Basis: Contributions of Working Group I to the Third Assessment Report of the Intergovernmental Panel on Climate Change, Cambridge University Press, 881 pp., 2001.

Climate Change 2007: IPCC 2007: The Physical Science Basis. Contribution of Working Group I to the Fourth Assessment Report of the Intergovernmental Panel on Climate Change, Solomon, S., Qin, D., Manning, M., Chen, Z., Marquis, M., Averyt, K. B., Tignor, M., and Miller, H. L., Cambridge University Press, Cambridge, UK and New York, NY, USA, 996 pp., USA.

Kaptue, T. A. T., Roujean, J. L., and Faroux, S.: ECOCLIMAP-II: an ecosystem classification and land surface parameters database of Western Africa at $1 \mathrm{~km}$ resolution for the African Monsoon Multidisciplinary Analysis (AMMA) project, Remote Sens. Environ., 114, 961-976, 2010.

Karyampudi, V. M., Palm, S. P., Reagen, J. A., Fang, H., Grant, W. B., Hoff, R. M., Moulin, C., Pierce, H. F., Torres, O., Browell, E. V., and Melfi, S. H.: Validation of the Saharan dust plume conceptual model using lidar, Meteosat, and ECMWF data, B. Am. Meteorol. Soc., 80, 1045-1075, 1999.

Kimura, R., Bai, L., and Wang, J.: Relationships among dust outbreaks, vegetation cover, and surface soil water content on the Loess Plateau of China, 1999-2000, Catena, 77(3), 292-296, 2009.

Lafore, J. P., Stein, J., Asencio, N., Bougeault, P., Ducrocq, V., Duron, J., Fischer, C., Hereil, P., Mascart, P., Masson, V., Pinty, J. P., Redelsperger, J. L., Richard, E., and Vila-Guerau de Arellano, J.: The Meso-NH Atmospheric Simulation System. Part I: adiabatic formulation and control simulations, Scientific objectives and experimental design, Ann. Geophys., available online at: http://mesonh.aero.obs-mip.fr/mesonh/, 16, 90-109, 1998.

Lamb, P. J.: West African water vapor variations between recent contrasting Subsaharan rainy seasons, Tellus, 35A, 198-212, 1983.

Lebel, T., Parker, D. J., Flamant, C., Bourles, B., Marticorena, B., Mougin, E., Peugeot, C., Diedhiou, A., Haywood, J. M., Ngamini, J. B., Polcher, J., Redelsperger, J.-L., and Thorncroft, C. D: The AMMA field campaigns: multiscale and multidisciplinary observations in the West African region, Q. J. Roy. Meteorol. Soc. 136, S1, 8-33, 2010.

Levin, Z., Joseph, J. H., and Mekler, Y.: Properties of Sharav (Khamsin) dust - comparison of optical and direct sampling data, J. Atmosph. Sci., 37, 882-891, 1980.

Levin, Z., Ganor, E., and Gladstein, V.: The effects of desert particles coated with sulfate on rain formation in the eastern Mediterranean, J. Appl. Meteor., 35, 1511-1523, 1996. 
Luo, C., Mahowald, N., and del Corral, J.: Sensitivity study of meteorological parameters on mineral aerosol mobilization, transport, and distribution, J. Geophys. Res., 108, 4447, doi:10.1029/2003JD003483, 2003.

Marticorena, B. and Bergametti, G.: Modeling of the atmospheric dust cycle: 1. design of a soil derived dust emission scheme, J. Geophys. Res., 100, 16415-16429, 1995.

Masson, V.: A physically-based scheme for the urban energy balance in atmospheric models, Bound.-Lay. Meteorol., 94, 357397, 2000.

Masson, V., Champeaux, J. L., Chauvin, F., Meriguet, C., and Lacaze, R.: A global database of land surface parameters at 1$\mathrm{km}$ resolution in meteorological and climate models, J. Climate, 16(9), 1261-1282, 2003.

Mathon, V. and Laurent, H.: Mesoscale convective system rainfall in the Sahel, J. Appl. Meteorol., 41, 1081-1092, 2002.

Middleton, N. J. and Goudie, A. S.: Saharan dust: sources and trajectories, Trans. Inst. Br. Geogr., 26, 165-181, 2001.

Miller, M. A. and Slingo, A.: The ARM Mobile Facility and its first international deployment: Measuring radiative flux divergence in West Africa, Bull. Am. Meteorol. Soc., 88, 1229-1244, 2007.

Noilhan, J. and Mahouf, J.: The isba land surface parametrisation scheme, Global Planet. Change, 13, 145-159, 1996.

Parker, D. J., Thorncroft, C. D., Burton, R. R., and Diongue-Niang, A.: Analysis of the African easterly jet, using aircraft observations from the JET2000 experiment, Q. J. Roy. Meteorol. Soc., 131, 1461-1482, 2005a

Parker D. J., Burton, R. R., Diongue-Niang, A., Ellis, R. J., Felton, M., Taylor, C. M., Thorncroft, C. D., Bessemoulin, P., and Tompkins, A. M.: The diurnal cycle of the west African monsoon circulation, Q. J. Roy. Meteorol. Soc., 131, 2839-2860, 2005 b.

Pinty, B., Verstraete, M. M., and Dickinson, R. E.: A physical mode1 for predicting bidirectional reflectances over bare soils. Remote Sens. Environ., 27, 273-288, 1989.

Pinty, J. P. and Jabouille, P.: A mixed-phase cloud parameterization for use in mesoscale non hydrostatic model: simulations of a squall line and of orographic precipitations, Conference of Cloud Physics, Everett, WA, USA, 217-220, 1998.

Prodi, F. and Fea, G.: A case of transport and deposition of Sahara dust over the Italian Peninsula and Southern Europe, J. Geophys. Res., 84C, 6951-6960, 1979.

Prospero, J. M.: Long-term measurements of the transport of African mineral dust to the southeastern United States: Implications for regional air quality, J. Geophys. Res., 104, 1591715927, 1999.

Redelsperger, J. L., Diedhiou, A., Flamant, C., Janicot, S., Lafore, J. P., Lebel, T., Polcher, J., Bourles, B., Caniaux, G., De Rosnay, P., Desbois, M., Eymard, L., Fontaine, B., Geneau, I., Ginoux, K., Hoepffner, M., Kane, C., Law, K., Mari, C., Marticorena, B., Mougin, E., Pelon, J., Peugeot, C.,Protat, A., Roux, F., Sultan, B., and Van Den Akker, E.: AMMA, une 'etude multidisciplinairede la mousson ouest africaine, La Météorologie, Aout 2006, 54, 22-32, 2006.

Reeves, C. E., Formenti, P., Afif, C., Ancellet, G., Attié, J.-L., Bechara, J., Borbon, A., Cairo, F., Coe, H., Crumeyrolle, S., Fierli, F., Flamant, C., Gomes, L., Hamburger, T., Jambert, C., Law, K. S., Mari, C., Jones, R. L., Matsuki, A., Mead, M. I., Methven, J., Mills, G. P., Minikin, A., Murphy, J. G., Nielsen, J. K., Oram, D. E., Parker, D. J., Richter, A., Schlager, H.,
Schwarzenboeck, A., and Thouret, V.: Chemical and aerosol characterisation of the troposphere over West Africa during the monsoon period as part of AMMA, Atmos. Chem. Phys., 10, 7575-7601, doi:10.5194/acp-10-7575-2010, 2010.

Sandu, I., Brenguier, J. L., Geoffroy, O., Thouron, O., and Masson, V.: Aerosol impacts on the diurnal cycle of marine stratocumulus, J. Atmos. Sci., 65, 2705-2718, 2008.

Stull, R. B.: An Introduction to Boundary Layer Meteorology, Kluwer Academic Publishers, Dordrecht, The Netherlands, 666 pp., 1988.

Suhre, K., Mari, C., Bates, T. S., Johnson, J. E., Rosset, R., Wang, Q., Bandy, A. R., Blake, D. R., Businger, S., Eisels, F. K., Huebert, B. J., Kok, G. L., Mauldin III, R. L., Prévôt, A. S. H., Schillawski, R. D., Tanner, D. J., and Thornton, T. C.: Physicochemical modeling of the first aerosol characterization experiment (ace 1) lagrangian b, 1. a moving column approach, J. Geophys. Res., 103, 16433-16455, 1998.

Talbot, R. W., Harriss, C., Browell, E. V., Gregory, G. L., Sebacher, D. I., and Beck, S. M.: Distribution and geochemistry of aerosols in the tropical North Atlantic troposphere: Relation to Saharan dust, J. Geophys. Res., 91, 5173-5182, 1986.

Taylor, C. M., Ellis, R. J., Parker, D. J., Burton, R. R., and Thorncroft, C. D.: Linking boundary-layer variability with convection: A case-study from JET2000, Q. J. R. Meteorol. Soc., 129, 2233 2254. doi:10.1256/qj.02.134. 2003.

Taylor, C. M., Parker, D. J., and Harris, P. P.: An observational case study of mesoscale atmospheric circulations induced by soil moisture, Geophys. Res. Lett., 34, L15801, doi:10.1029/2007GL030572, 2007.

Todd, M. C., Bou Karam, D., Cavazos, C., Bouet, C., Heinold, B., Baldasano, J. M., and Cautenet, A.: Quantifying uncertainty in estimates of mineral dust flux: An intercomparison of model performance over the Bodélé Depression, northern Chad, J. Geophys. Res., 113, D24107, doi:10.1029/2008JD010476, 2008a.

Todd, M. C., Washington, R., Lizcano, G., Ragvahan, S., and Knippertz, P.: Regional model simulations of the Bodélé low-level jet of Northern Chad during BoDEx 2005, J. Clim., 21, 995-1012, 2008 b.

Tulet, P., Crassier, V., Solmon, F., Guedalia, D., and Rosset, R.: Description of the mesoscale nonhydrostatic chemistry model and application to a transboundary pollution episode between northern france and southern england, J. Geophys. Res., 108(D1), 4021, doi:10.1029/2000JD000301, 2003.

Tulet, P., Crassier, V., Cousin, F., Shure, K., and Rosset, R.: Orilam, a three moment lognormal aerosol scheme for mesoscale atmospheric model, on-line coupling into the mesonh-c model and validation on the escompte campaign, J. Geophys. Res., 110, D18201, doi:10.1029/2004JD005716, 2005.

Tulet, P., Mallet, M., Pont, V., Pelon, J., and Boon, A.: The 713 March 2006 dust storm over West Africa: Generation, transport, and vertical stratification, J. Geophys. Res., 113, D00C08, doi:10.1029/2008JD009871, 2008.

Tulet P., Crahan-Kaku, K., Leriche, M., Aouizerats, B., and Crumeyrolle, S.: Mixing of dust aerosols into a mesoscale convective system: Generation, filtering and possible feedbacks on ice anvils, Atmospheric Research, 96(2-3), 15th International Conference on Clouds and Precipitation - ICCP 2008, ISSN 0169-8095, 302-314, doi:10.1016/j.atmosres.2009.09.011, 2010. 
Twomey, S.: The influence of pollution on the shortwave albedo of clouds, J. Atmos. Sci., 34, 1149-1152, 1977.

Warren, A., Chappell, A., Todd, M. C., Bristow, C., Drake, N., Engelstaedter, S., Martins, V., M'Bainayel, S., and Washington, R.: Dust-raising in the dustiest place on Earth, Geomorphology, 92, 25-37, doi:10.1016/j.geomorph.2007.02.007, 2007.

Washington, R. and Todd, M. C.: Atmospheric controls on mineral dust emission from the Bodélé Depression, Chad: The role of the low-level jet, Geophys. Res. Lett., 32, L17701, doi:10.1029/2005GL023597, 2005.
Washington, R., Todd, M. C., Engelstaedter, S., Mbainayel, S., and Mitchell, F.: Dust and the low-level circulation over the Bodele Depression, Chad: Observations from BoDEx 2005, J. Geophys. Res., 111, D03201, doi:10.1029/2005JD006502, 2006.

Zender C. S., Bian, H., and Newman, D.: The mineral dust entrainment and deposition (DEAD) model: Description and global dust distribution, J. Geophys. Res., 108(D14), 4416, doi:10.1029/2002JD002775, http://dust.ess.uci.edu/dead/, 2003. 